Supporting Information

for

\title{
Supramolecular Antagonists Promote Mitochondrial Dysfunction
}

Mingming Li ${ }^{1}$, Yanqiu Song ${ }^{l}, \mathrm{Na}$ Song ${ }^{1}$, Guangyao $\mathrm{Wu}^{1}$, Hao Zhou ${ }^{2}$, Jiafu Long ${ }^{2}$, Pengcheng Zhang ${ }^{3}$, Linqi Shi ${ }^{l}$, and Zhilin $Y u^{l} *$

${ }^{1}$ Key Laboratory of Functional Polymer Materials, Ministry of Education, State Key Laboratory of Medicinal Chemical Biology, Institute of Polymer Chemistry, College of Chemistry, Nankai University, 94 Weijin Road, Tianjin 300071, China

${ }^{2}$ Key Laboratory of Medicinal Chemical Biology, Tianjin Key Laboratory of Protein Science, College of Life Sciences, Nankai University, 94 Weijin Road, Tianjin 300071, China

${ }^{3}$ State Key Laboratory of Drug Research \& Center for Pharmaceutics, Shanghai Institute of Materia Medica, Chinese Academy of Sciences, 501 Haike Road, Shanghai 201203, China 


\section{CONTENTS:}

1. General Materials

2. Synthesis of Fmoc-L-3-(3-methylpyridyl)-alanine

3. Synthesis of 2-(pyridin-2-yldisulfanyl) ethanol

4. Synthesis of camptothecin-(4-pyridyldisulfanyl)ethyl carbonate

5. Syntheses of Peptides Py ${ }^{\mathrm{Me}} \mathrm{Amp}$, Cys-Py ${ }^{\mathrm{Me}} \mathrm{Amp}, \mathrm{Py}^{\mathrm{Me}} \mathrm{AmpB}$, and BH3 PEP

6. Synthesis of peptide PyMeAmp-CPT

7. Dye-labeled peptides

8. Preparation of the coassemblies

9. Critical aggregation concentration (CAC)

10. Circular dichroism (CD) spectroscopy

11. Fourier transform infra-red (FTIR) spectroscopy

11. Atom Force Microscopy (AFM)

12. Transmission electron microscopy (TEM)

13. Dynamic light scattering studies (DLS)

14. GSH-induced CPT-release from $\mathrm{Py}^{\mathrm{Me}} \mathrm{AmpBC}$

15 . In vitro cytotoxicity

16. Endo/lysosomal escape studies

17. Mitochondrion-targeting assays

18. Cell apoptosis studies

19. Bio-TEM studies of HeLa cells

20. Microscale thermophoresis (MST) assays

21. JC-1 detection of mitochondrial membrane potential

22. Weston blot studies

23. Caspase- 9 or caspase- 3 activity assay

24. In vivo and ex vivo imaging

25. In vivo tumor therapy

26. Figures S1-S54 


\section{General materials}

2-Chlorotrityl chloride resin (loading density: $0.5 \mathrm{mmol} / \mathrm{g}$ ) was purchased from ApexBio Technology Co., Ltd. All Fmoc-protected amino acids, O-Benzotriazole-N,N,N,N-tetramethyl-uroniumhexafluorophosphate (HBTU), and N, N'-diisopropylethylamine (DIEA) used in solid-phase peptide synthesis were acquired from Bide Pharmatech Co., Ltd. Trifluoroacetic acid (TFA) and triisopropylsilane(TIPS) were obtained from Meryer Chemical Technology Co. Ltd. Piperidine was supplied by Sinopharm Chemical Reagent. Dichloromethane $\left(\mathrm{CH}_{2} \mathrm{Cl}_{2}\right)$, methanol $\left(\mathrm{CH}_{3} \mathrm{OH}\right), \mathrm{N}, \mathrm{N}^{\prime}-$ dimethylformamide (DMF), diethyl ether, acetonitrile, petroleum ether (PE), and ethyl acetate (EtOAc) were purchased from Tianjin Bohua Chemical Reagent. Methyl iodide, 2-mercaptoethanol, dithiopyridine, camptothecin (CPT), 4-dimethylaminopyridine (DMAP), and triphosgene were obtained from Energy Chemical. 3-(4,5-Dimethylthiazol-2-yl)-2,5-diphenyltetrazolium bromide (MTT), 4',6-diamidino-2-phenylindole (DAPI) were obtained from Sigma-Aldrich. Mito-Tracker Red CMXRos, Lyso-Tracker Red DND-26, JC-1, and Annexin V-FITC/PI cell apoptosis detection kit were supplied by Dalian Meilun Biotech Co., Ltd. Ultrapure water was produced by Arium Pro Ultrapure water systems (Sartorius, $18.2 \mathrm{M} \Omega$ ).

\section{Synthesis of Fmoc-L-3-(3-methylpyridyl)-alanine}

Fmoc-L-3-(3-pyridyl)-alanine (194 mg, $0.5 \mathrm{mmol}$ ) was dissolved in $1 \mathrm{~mL}$ of acetonitrile (50 $\mu \mathrm{L} \mathrm{DMF}$ to aid solubility), to which methyl iodide $(62 \mu \mathrm{L}, 0.5 \mathrm{mmol})$ was added dropwise. The mixture was stirred for $8 \mathrm{~h}$ at room temperature. $10 \mathrm{~mL}$ of diethyl ether was slowly added to the reaction until appearance of the white precipitate. The white precipitate was collected by centrifugation and washed twice with diethyl ether, leading to the product used without further purification. 


\section{Synthesis of 2-(pyridin-2-yldisulfanyl) ethanol ${ }^{[1]}$}

Under a nitrogen atmosphere, dithiopyridine $(1 \mathrm{~g}, 5 \mathrm{mmol})$ was dissolved in $10 \mathrm{~mL}$ of methanol in a two-necked flask. And then 2-mercaptoethanol $(160 \mu \mathrm{L}, 2 \mathrm{mmol})$ was added dropwise to the solution. The solution gradually turned yellow and was stirred at room temperature for 24 hours. The solvent was removed by rotary evaporation to obtain a crude product, which was purified by silica chromatography (petroleum ether: ethyl acetate $=4: 1$ ).

\section{Synthesis of camptothecin-(4-pyridyldisulfanyl)ethyl carbonate ${ }^{[2]}$}

DMAP (675 mg, $5.4 \mathrm{mmol})$ and CPT (450 mg, $1.29 \mathrm{mmol})$ were dissolved in anhydrous $\mathrm{CH}_{2} \mathrm{Cl}_{2}$ $(60 \mathrm{~mL})$ and stirred for $5 \mathrm{~min}$. Then triphosgene $(198 \mathrm{mg}, 0.72 \mathrm{mmol})$ was added to the solution under nitrogen atmosphere and further stirred for 15 minutes at room temperature. Then, 2-(pyridin-2yldisulfide) ethanol (390 mg, $2.1 \mathrm{mmol}$ ) was added to the reaction solution, and stirring was continued for 16 hours. After removing the organic solvent by rotary evaporation, a small amount of hot methanol was added and recrystallized at $4{ }^{\circ} \mathrm{C}$ to obtain a light brown precipitate, which was collected by filtration and dried under vacuum, leading to the product.

\section{Syntheses of Peptides Py ${ }^{\mathrm{Me}}$ Amp, Cys-Py ${ }^{\mathrm{Me}}$ Amp, $\mathrm{Py}^{\mathrm{Me}}$ AmpB, and BH3 PEP}

Peptides Py ${ }^{\mathrm{Me}} \mathrm{Amp}$, Cys-Py ${ }^{\mathrm{Me}} \mathrm{Amp}, \mathrm{Py}^{\mathrm{Me}} \mathrm{AmpB}$, and BH3 PEP were synthesized via standard Fmoc solid-phase peptide synthesis (SPPS) method. While peptides $\mathrm{Py}^{\mathrm{Me}} \mathrm{Amp}$, Cys-Py ${ }^{\mathrm{Me}} \mathrm{Amp}$, and $\mathrm{Py}^{\mathrm{Me}} \mathrm{AmpB}$ were synthesized on 2-chlorotrityl chloride resin, peptide BH3 PEP was synthesized using Rink amide resin. In the cases of 2-chlorotrityl chloride resin syntheses, 2-chlorotrityl chloride resin 
was swelled in anhydrous $\mathrm{CH}_{2} \mathrm{Cl}_{2}$ for $30 \mathrm{~min}$. Then a mixture of $\mathrm{Fmoc}-\mathrm{Phe}-\mathrm{OH}$ (4 eq. relative to resin), DIEA (6 eq.) in anhydrous $\mathrm{CH}_{2} \mathrm{Cl}_{2}$ was added to 2-chlorotrityl chloride resin. After $1 \mathrm{~h}, \mathrm{CH}_{3} \mathrm{OH}$ was added and shaken for another $30 \mathrm{~min}$ to terminate the resin sealing process. The sealed resin was successively washed by DMF and $\mathrm{CH}_{2} \mathrm{Cl}_{2}$. In the cases of attaching the left amino acids on 2chlorotrityl chloride resin or attaching all amino acids on Rink amide resin, amino acid coupling reactions were carried out by dissolving a mixture of amino acid / HBTU / DIEA (4 : $3.95: 6$ relative to the resin) in DMF.

\section{Synthesis of peptide $\mathrm{Py}^{\mathrm{Me}} \mathrm{Amp}-\mathrm{CPT}$}

The purified peptide (Cys-Py $\left.{ }^{\mathrm{Me}} \mathrm{Amp}\right)(126.7 \mathrm{mg}, 154.4 \mu \mathrm{mol})$, camptothecin-(4-pyridyldisulfide), and ethyl carbonate $(110.8 \mathrm{mg}, 200 \mu \mathrm{mol})$ were dissolved in anhydrous DMSO and stirred at room temperature for $24 \mathrm{~h}$. The DMSO in the solution was lyophilized to obtain the crude peptide $\mathrm{Py}^{\mathrm{Me}} \mathrm{AmpC}$, which was purified by preparative RP-HPLC.

\section{Dye-labeled peptides}

FAM-labeled peptides AmpF-FAM, Py ${ }^{\mathrm{Me}} \mathrm{Amp}-\mathrm{FAM}$, and BH3 PEP-FAM were synthesized via standard SPPS method. The pre-prepared resin (AmpF, $\mathrm{Py}^{\mathrm{Me}} \mathrm{Amp}$ and $\mathrm{BH} 3$ peptide) were swelled in $\mathrm{CH}_{2} \mathrm{Cl}_{2}$ for $30 \mathrm{~min}$. Then a mixture of 5-carboxyfluorescein (5-FAM-COOH) (4 eq. relative to resin), DIEA (6 eq.) and HBTU (3.95 eq.) in DMF was added to the swelled resin and shaken for 2 hours in the dark. All the peptides were cleaved from the resin using a cocktail of $50 \%$ trifluoroacetic acid in $\mathrm{CH}_{2} \mathrm{Cl}_{2}$ for $1 \mathrm{~h}$. After removing the organic solvent and precipitating by cold diethyl ether, the collected crude product was further purified by RP-HPLC. The FAM-labeled peptides AmpF-FAM, Py ${ }^{\mathrm{Me}} \mathrm{Amp}-$ 
FAM, and BH3 PEP-FAM were integrated into AmpF, $\mathrm{Py}^{\mathrm{Me}} \mathrm{Amp}, \mathrm{Py}^{\mathrm{Me}} \mathrm{AmpB}, \mathrm{Py}^{\mathrm{Me}} \mathrm{AmpC}$, $\mathrm{Py}^{\mathrm{Me}} \mathrm{AmpBC}$, and $\mathrm{BH} 3$ PEP samples with a percentage of $5 \%$ to the total peptide concentration to provide fluorescence signals.

\section{Preparation of the coassemblies}

To prepare coassemblies $\mathrm{Py}^{\mathrm{M}} \mathrm{e} A m p B, \mathrm{Py}^{\mathrm{Me}} \mathrm{AmpC}$, and $\mathrm{Py}^{\mathrm{Me}} \mathrm{AmpBC}$, the stock solutions with a concentration of $10 \mathrm{mM}$ for peptide $\mathrm{Py}^{\mathrm{Me}} \mathrm{Amp}, \mathrm{Py}^{\mathrm{Me}} \mathrm{Amp}-\mathrm{CPT}$, or $\mathrm{Py}^{\mathrm{Me}} \mathrm{Amp}-\mathrm{BH} 3$ were initially prepared by dissolving the lyophilized peptide powder in PBS buffer. We initially prepared the coassemblies of peptides $\mathrm{Py}^{\mathrm{Me}} \mathrm{Amp}, \mathrm{Py}^{\mathrm{Me}} \mathrm{Amp}-\mathrm{BH} 3$, and $\mathrm{Py}^{\mathrm{Me}} \mathrm{Amp}-\mathrm{CPT}$ in various molar ratios including $85: 10: 5,75: 10: 15,75: 20: 5,60: 10: 30$, or $60: 35: 5$, by mixing the solution of peptides $\mathrm{Py}^{\mathrm{Me}} \mathrm{Amp}, \mathrm{Py}^{\mathrm{Me}} \mathrm{Amp}-\mathrm{BH} 3$, and $\mathrm{Py}^{\mathrm{Me}} \mathrm{Amp}-\mathrm{CPT}$ with a corresponding volume ratio. The resulting coassemblies were aged for 2 days for thermodynamic equilibration prior to $\mathrm{CD}$ studies, which was shown as Figure S13. CD results indicated that the coassemblies with a content of peptide $\mathrm{Py}^{\mathrm{Me}} \mathrm{Amp}$ below $85 \%$ did not show the conventional $\mathrm{CD}$ signals for $\beta$-sheets at $\mathrm{pH} 7.4$, whereas the coassemblies containing $85 \%$ peptide $\mathrm{Py}^{\mathrm{Me}} \mathrm{Amp}$ exhibited the $\beta$-sheet signals. These results indicate the interrupted formation of well-defined secondary structures and nanostructures via increasing the functionalized counterparts. In addition, the previous references demonstrate that the binding constant of BH3 domain to protein Bcl-2 family and the IC50 value of drug CPT to cancer cells were approximately 10 and 5 $\mu \mathrm{M}$, respectively. ${ }^{[3,4]}$ Hence we maintained the molar ratio between $\mathrm{Py}^{\mathrm{Me}} \mathrm{Amp}-\mathrm{BH} 3$ and $\mathrm{Py}^{\mathrm{Me}} \mathrm{Amp}-$ CPT to be 2:1 in the coassembly $\mathrm{Py}^{\mathrm{Me}} \mathrm{AmpBC}$. Based on these considerations, we prepared the coassembled therapeutics of $\mathrm{Py}^{\mathrm{Me}} \mathrm{Amp}, \mathrm{Py}^{\mathrm{Me}} \mathrm{Amp}-\mathrm{BH} 3$, and $\mathrm{Py}^{\mathrm{Me}} \mathrm{Amp}-\mathrm{CPT}$ in a molar ratio of 8.5:1.0:0.5 by mixing their stock solutions in a volume ratio of $85: 10: 5$ and diluting with water to the 
solution of $\mathrm{Py}^{\mathrm{Me}} \mathrm{AmpBC}$ with a concentration of $5 \mathrm{mM}$. Under the identical protocol, $\mathrm{Py}{ }^{\mathrm{Me}} \mathrm{AmpB}$ and $\mathrm{Py}^{\mathrm{Me}} \mathrm{AmpC}$ were prepared by mixing the solution of peptides $\mathrm{Py}^{\mathrm{Me}} \mathrm{Amp}$ and $\mathrm{Py}^{\mathrm{Me}} \mathrm{Amp}-\mathrm{BH}$, or peptides $\mathrm{Py}^{\mathrm{Me}} \mathrm{Amp}$ and $\mathrm{Py}^{\mathrm{Me}} \mathrm{Amp}-\mathrm{CPT}$, in a molar ratio of 90:10 and 95: 5, respectively. For the solution of the coassemblies at $\mathrm{pH} 6.5$, diluting $\mathrm{HCl}$ was used to adjust the solution $\mathrm{pH}$. The fresh solutions of $\mathrm{Py}^{\mathrm{Me}} \mathrm{AmpB}, \mathrm{Py}^{\mathrm{Me}} \mathrm{AmpC}$, and $\mathrm{Py}^{\mathrm{Me}} \mathrm{AmpBC}$ were aged for 2 days for thermodynamic equilibration prior to all characterizations and biological studies.

\section{Critical aggregation concentration (CAC)}

Using Nile Red as the fluorescent probe, the CAC value of $\mathrm{Py}^{\mathrm{Me}} \mathrm{Amp}, \mathrm{Py}^{\mathrm{Me}} \mathrm{AmpB}, \mathrm{Py}^{\mathrm{Me}} \mathrm{AmpC}$, and $\mathrm{Py}^{\mathrm{Me}} \mathrm{AmpBC}$ were estimated based on the shift of the maximal emission of Nile Red in the presence of the peptides at various concentrations. Different concentrations of peptide solutions $(1.5 \mathrm{~mL})$ were obtained by graduately diluting the stock solution $(5 \mathrm{mM})$. Subsequently, $1.5 \mu \mathrm{L}$ of Nile Red solution (100 $\mu \mathrm{M}$ in ethanol) was added to each peptide solution, leading to the samples containing Nile Red with a concentration of $100 \mathrm{nM}$. The resulting samples were then aged overnight prior to measurement. The fluorescence spectra of Nile Red were recorded by the Agilent Cary Eclipse fluorescence spectrophotometer with an excitation wavelength of $550 \mathrm{~nm}$.

\section{Circular dichroism (CD) spectroscopy}

CD spectra were recorded by a Biologic MOS-500 spectrometer using $0.1 \mathrm{~mm}$ quartz slides at $25{ }^{\circ} \mathrm{C}$. All scans were recorded with a wavelength interval of $1.0 \mathrm{~nm}$ and in the range from 190 to $260 \mathrm{~nm}$. All the CD samples of $\mathrm{Py}^{\mathrm{Me}} \mathrm{Amp}, \mathrm{Py}^{\mathrm{Me}} \mathrm{AmpB}, \mathrm{Py}^{\mathrm{Me}} \mathrm{AmpC}$, and $\mathrm{Py}^{\mathrm{Me}} \mathrm{AmpBC}$ at different $\mathrm{pH}(7.4$ or 6.5) were prepared by diluting the stock solution $(5 \mathrm{mM})$ to a concentration of $2 \mathrm{mM}$. 


\section{Fourier transform infra-red (FTIR) spectroscopy}

The FTIR samples of $\mathrm{Py}^{\mathrm{Me}} \mathrm{Amp}, \mathrm{Py}^{\mathrm{Me}} \mathrm{AmpB}, \mathrm{Py}^{\mathrm{Me}} \mathrm{AmpC}$, and $\mathrm{Py}^{\mathrm{Me}} \mathrm{AmpBC}$ were prepared by dropping the stock peptide solutions $(5 \mathrm{mM})$ on the quartz detector and allowed to be dried under atmospheric condition. All spectra were recorded on a TENSOR II FTIR spectrometer (Bruker) in the wavenumber region from 4000 to $400 \mathrm{~cm}^{-1}$.

\section{Atom force microscopy (AFM)}

AFM images of $\mathrm{Py}^{\mathrm{Me}} \mathrm{Amp}, \mathrm{Py}^{\mathrm{Me}} \mathrm{AmpB}, \mathrm{Py}^{\mathrm{Me}} \mathrm{AmpC}$, and $\mathrm{Py}^{\mathrm{Me}} \mathrm{AmpBC}$ at different $\mathrm{pH}$ (7.4 or 6.5) were taken by a CSPM 5500 instrument under the tapping mode. AFM samples were obtained by diluting the stock solutions of $\mathrm{Py}^{\mathrm{Me}} \mathrm{Amp}, \mathrm{Py}^{\mathrm{Me}} \mathrm{AmpB}, \mathrm{Py}^{\mathrm{Me}} \mathrm{AmpC}$ and $\mathrm{Py}^{\mathrm{Me}} \mathrm{AmpBC}$ to a concentration of $1 \mathrm{mM}$ and pipetting $10 \mu \mathrm{L}$ on the freshly cleaved mica surface for $5 \mathrm{~min}$, then removing the retained solution by filter paper. The samples were dried under atmospheric condition before measurement.

\section{Transmission electron microscopy (TEM)}

TEM images were recorded by HITACHI HT7700 Exalens microscope at an accelerating voltage of $100 \mathrm{kV}$. TEM samples were prepared by diluting the stock peptides solution of $\mathrm{Py}^{\mathrm{Me}} \mathrm{Amp}, \mathrm{Py}^{\mathrm{Me}} \mathrm{AmpB}$, $\mathrm{Py}^{\mathrm{Me}} \mathrm{AmpC}$, and $\mathrm{Py}^{\mathrm{Me}} \mathrm{AmpBC}(5 \mathrm{mM})$ to a concentration of $2 \mathrm{mM}$ and dropping $8 \mu \mathrm{L}$ on the carboncoated copper grid for $5 \mathrm{~min}$. Then the remained solution was removed by the filter paper. At last, all samples were stained by $5 \mu \mathrm{L}$ of $2 \mathrm{wt} \%$ uranyl acetate solution and blotted by the filter paper after $4 \mathrm{~min}$. The grid was dried in a desiccator prior to measurement. 


\section{Dynamic light scattering studies (DLS)}

DLS samples were prepared by diluting the stock peptides solution of $\mathrm{Py}^{\mathrm{Me}} \mathrm{Amp}, \mathrm{Py}^{\mathrm{Me}} \mathrm{AmpB}$, $\mathrm{Py}^{\mathrm{Me}} \mathrm{AmpC}$, and $\mathrm{Py}^{\mathrm{Me}} \mathrm{AmpBC}(5 \mathrm{mM})$ to a concentration of $2 \mathrm{mM}$ and filtering nylon membrane to eliminate the interference of dust in the air. Then DLS measurements were carried out on ZETAPALS/BI-200SM (BROOKHAVEN, USA).

\section{GSH-induced CPT-release from $\mathrm{Py}^{\mathrm{Me}} \mathrm{AmpBC}$}

GSH-induced release of CPT from $\mathrm{Py}^{\mathrm{Me}} \mathrm{AmpBC}$ was evaluated by using UV/vis absorption spectra. Prior to monitoring CPT release, we prepared a standard curve by plotting the UV/vis absorption intensity at $369 \mathrm{~nm}$ of peptide $\mathrm{Py}^{\mathrm{Me}} \mathrm{Amp}-\mathrm{CPT}$ (CPT concentration: from 1.8 to $80 \mu \mathrm{M}$ ). To a PBS solution of $\mathrm{Py}^{\mathrm{Me}} \mathrm{AmpBC}$ with a concentration of $1.0 \mathrm{mM}$ (CPT moiety: $\left.50 \mu \mathrm{M}\right)$, GSH (10 mM) was added. The mixture was transferred to a dialysis tube (molecular weight cutoff: $1000 \mathrm{Da}$ ) immersed in PBS buffer containing $10 \mathrm{mM} \mathrm{GSH}$ at $37^{\circ} \mathrm{C}$. Then we recorded the absorption intensity at $369 \mathrm{~nm}$ using UV/vis spectroscope (Agilent Cary $60 \mathrm{UV}$-Vis) at $0,1,2,4,6,8,10,12,14$ and 24 h post GSH addition.

\section{In vitro cytotoxicity}

The cytotoxicity of peptides and the coassemblies was determined by using the standard MTT test. In the case of peptide $\mathrm{Py}^{\mathrm{Me}} \mathrm{Amp}$, HeLa, 293T, or $3 \mathrm{~T} 3$ cells were used. All cells were acquired from the Cell Bank of the Chinese Academy of Sciences. In the cases of other peptides and the coassemblies, only HeLa cells were used. Briefly, the used cells were seeded in the 96-well plate with a density of 5000 cells per well in $100 \mu \mathrm{L}$ of DMEM medium containing $10 \%$ FBS and $1 \%$ penicillin- 
streptomycin. After $24 \mathrm{~h}$ pre-incubation, the cells were incubated with $\mathrm{Py}^{\mathrm{Me}} \mathrm{Amp}, \mathrm{Py}^{\mathrm{Me}} \mathrm{AmpB}$, $\mathrm{Py}^{\mathrm{Me}} \mathrm{AmpC}, \mathrm{Py}{ }^{\mathrm{Me}} \mathrm{AmpBC}$, free CPT, or BH3 PEP at different concentrations (doses of CPT moiety: 0, $0.15,0.3,0.6,1.25,2.5,5$, and $7.5 \mu \mathrm{M}$, or doses of BH3 domain: $0,0.3,0.6,1.2,2.5,5,10$, and $15 \mu \mathrm{M}$ ) for $48 \mathrm{~h}$. Subsequently, MTT solution $(10 \mu \mathrm{L}, 5 \mathrm{mg} / \mathrm{mL})$ was added and further cultured for $4 \mathrm{~h}$. Finally, the supernatant was removed and $100 \mu \mathrm{L}$ of DMSO was injected into each well to dissolve the purple crystals. The cell viability was measured on a microplate reader (TECAN Infinite M Nano) via recording the absorption intensity at $495 \mathrm{~nm}$.

\section{Cellular uptake studies}

HeLa cells were cultured in a confocal glass-bottom plate $\left(10^{2} \mathrm{~mm}\right)\left(1.2 \times 10^{5}\right.$ cells/well $)$ in DMEM medium containing $10 \%$ fetal bovine serum (FBS) and $1 \%$ penicillin-streptomycin under the atmosphere of $5 \% \mathrm{CO}_{2}$ at $37{ }^{\circ} \mathrm{C}$ overnight. Afterwards, the cells were washed with PBS and cultured in $1 \mathrm{~mL}$ of fresh serum-free medium in the presence of peptide treatments $\mathrm{Py}^{\mathrm{Me}} \mathrm{Amp}, \mathrm{Py}^{\mathrm{Me}} \mathrm{AmpB}$, $\mathrm{Py}^{\mathrm{Me}} \mathrm{AmpC}, \mathrm{Py}^{\mathrm{Me}} \mathrm{AmpBC}$ or BH3 PEP containing the corresponding FAM-labeled peptide (a dose of $2 \mu \mathrm{M}$ for FAM moiety) for $2,4,8$, or $10 \mathrm{~h}$. After washing the cells twice with PBS, the cells were fixed with $4 \%$ paraformaldehyde for 20 min and stained with 4',6-diamidino-2-phenylindole (DAPI) for another $20 \mathrm{~min}$. Eventually, the cells internalizing $\mathrm{Py}^{\mathrm{Me}} \mathrm{Amp}, \mathrm{Py}^{\mathrm{Me}} \mathrm{AmpB}, \mathrm{Py}^{\mathrm{Me}} \mathrm{AmpC}$, $\mathrm{Py}^{\mathrm{Me}} \mathrm{AmpBC}$ or BH3 PEP were imaged by confocal laser scanning microscope (NIKON A1+). The cellular uptake of $\mathrm{Py}^{\mathrm{Me}} \mathrm{Amp}, \mathrm{Py}^{\mathrm{Me}} \mathrm{AmpB}, \mathrm{Py}^{\mathrm{Me}} \mathrm{AmpC}, \mathrm{Py}^{\mathrm{Me}} \mathrm{AmpBC}$ or BH3 PEP was also estimated by flow cytometry. HeLa cells $\left(1.5 \times 10^{5}\right.$ cells per well) seeded in 6-well plates were cultured for $24 \mathrm{~h}$ under the atmosphere of $5 \% \mathrm{CO}_{2}$ at $37^{\circ} \mathrm{C}$. Then the cells were washed with PBS and cultured in 1 $\mathrm{mL}$ fresh serum-free DMEM medium in the presence of peptide treatments $\mathrm{Py}^{\mathrm{Me}} \mathrm{Amp}, \mathrm{Py}^{\mathrm{Me}} \mathrm{AmpB}$, 
$\mathrm{Py}^{\mathrm{Me}} \mathrm{AmpC}, \mathrm{Py}{ }^{\mathrm{Me}} \mathrm{AmpBC}$ or BH3 PEP containing the corresponding FAM-labeled peptide (a dose of $2 \mu \mathrm{M}$ for FAM moiety) for $2,4,8$, or $10 \mathrm{~h}$. Then the cells were trypsinized and thoroughly washed with PBS. Re-suspending the incubated cells in $500 \mu \mathrm{L}$ PBS allows for carrying out flow cytometric analysis (BD LSR Fortessa).

\section{Endo/lysosomal escape studies}

HeLa cells in DMEM medium were seeded in confocal glass-bottom plate with a density of $1.2 \times 10^{5}$. Peptide treatments $\mathrm{Py}^{\mathrm{Me}} \mathrm{Amp}, \mathrm{Py}^{\mathrm{Me}} \mathrm{AmpB}, \mathrm{Py}^{\mathrm{Me}} \mathrm{AmpC}, \mathrm{Py}^{\mathrm{Me}} \mathrm{AmpBC}$ or $\mathrm{BH} 3$ PEP containing the corresponding FAM-labeled peptide (a dose of $2 \mu \mathrm{M}$ for FAM moiety) were added to the cells and incubated for 2, 4, 8, and $10 \mathrm{~h}$. Subsequently, the cells were incubated at $37^{\circ} \mathrm{C}$ with Lyso-Tracker Red (50 nM) for 30 min. After fixing with $4 \%$ paraformaldehyde for 20 min and staining with DAPI for another $20 \mathrm{~min}$, the cells were washed three times with PBS and imaged by confocal laser scanning microscope (NIKON A1+).

\section{Mitochondrion-targeting assays}

HeLa cells in DMEM medium $(1 \mathrm{~mL})$ are cultured in a confocal glass-bottom plate with a density of $1.2 \times 10^{5}$ for $24 \mathrm{~h}$. The cells are incubated in the presence of peptide treatments $\mathrm{Py}^{\mathrm{Me}} \mathrm{Amp}, \mathrm{Py}^{\mathrm{Me}} \mathrm{AmpB}$, $\mathrm{Py}^{\mathrm{Me}} \mathrm{AmpC}, \mathrm{Py}^{\mathrm{Me}} \mathrm{AmpBC}$ or BH3 PEP containing the corresponding FAM-labeled peptide (a dose of $2 \mu \mathrm{M}$ for FAM moiety) for 2, 4, 8, or $10 \mathrm{~h}$. After washing with PBS for three times, the cells are treated with Mito-Tracker Red for $30 \mathrm{~min}$ and fixed with $4 \%$ paraformaldehyde for 20 min and stained with DAPI for another $20 \mathrm{~min}$. The stained cells were washed three times with PBS and imaged by a confocal laser scanning microscope (NIKON A1+) with 60×oil lens. 


\section{Cell apoptosis studies}

HeLa cells in DMEM medium were seeded in 12 -well plates with a density of $1 \times 10^{5}$ cells per well overnight. After incubation with different treatments $\mathrm{PBS}, \mathrm{Py}^{\mathrm{Me}} \mathrm{Amp}, \mathrm{BH} 3 \mathrm{PEP}, \mathrm{Py}^{\mathrm{Me}} \mathrm{AmpB}$, free CPT, $\mathrm{Py}^{\mathrm{Me}} \mathrm{AmpC}$, and $\mathrm{Py}{ }^{\mathrm{Me}} \mathrm{AmpBC}$ (dose of CPT moiety: $2.5 \mu \mathrm{M}$, or dose of BH3 domain: $5 \mu \mathrm{M}$ ) for $12 \mathrm{~h}$, the cells were collected and stained with Annexin V-FITC $(5 \mu \mathrm{L})$ and PI solution $(5 \mu \mathrm{L})$ in binding buffer $(100 \mu \mathrm{L})$ for $15 \mathrm{~min}$ in dark. The cells were washed by PBS buffer for three time and detected under a flow cytometer (BD LSR Fortessa, USA). Q1, Q2, Q3, and Q4 represented dead cells, late apoptosis cells, early apoptosis cells, and vital cells, respectively. Furthermore, HeLa cells were seeded in the 12-well plates and incubated for $24 \mathrm{~h}$. After incubation in the presence of PBS, $\mathrm{Py}^{\mathrm{Me}} \mathrm{Amp}, \mathrm{BH} 3$ PEP, $\mathrm{Py}^{\mathrm{Me}} \mathrm{AmpB}$, free $\mathrm{CPT}, \mathrm{Py}^{\mathrm{Me}} \mathrm{AmpC}$, or $\mathrm{Py}^{\mathrm{Me}} \mathrm{AmpBC}$ (dose of CPT moiety: $2.5 \mu \mathrm{M}$, or dose of BH3 domain: $5 \mu \mathrm{M}$ ) for $12 \mathrm{~h}$, the HeLa cells were collected and stained by Calcein-AM/PI for 20 min in the dark at $37^{\circ} \mathrm{C}$. Afterwards, the cells were imaged by confocal laser scanning microscope (NIKON A1+).

\section{Bio-TEM studies of HeLa cells}

In order to demonstrate the accumulation of the supramolecular antagonist $\mathrm{Py}^{\mathrm{Me}} \mathrm{AmpBC}$ at mitochondria, we synthesized one iodinated peptide, i.e. AmpF-I, and integrated it to the supramolecular antagonist with a molar ratio of 5: 80:10:5 for AmpF-I, $\mathrm{Py}^{\mathrm{Me}} \mathrm{Amp}, \mathrm{Py}^{\mathrm{Me}} \mathrm{Amp}-\mathrm{BH}$, and $\mathrm{Py}^{\mathrm{Me}} \mathrm{Amp}-\mathrm{CPT}$, respectively, leading to iodinated supramolecular antagonist $\mathrm{Py}^{\mathrm{Me}} \mathrm{AmpBC}-\mathrm{I}$. The energy-dispersive X-ray spectrum (EDS) of the TEM image were carried out to confirm accumulation of peptide nanofibers along mitochondria within HeLa cells. Hela cells were seeded in 6-well plates 
with a density of $1.5 \times 10^{5}$ cells per well overnight. After incubation with PBS or $\mathrm{Py}^{\mathrm{Me}} \mathrm{AmpBC}-\mathrm{I}$ (dose of CPT moiety: $2.5 \mu \mathrm{M}$, or dose of BH3 domain: $5 \mu \mathrm{M}$ ) for $10 \mathrm{~h}$, the cells were trypsinized and thoroughly washed with PBS following by fixing in $2.5 \%$ glutaraldehyde overnight. After removing the fixing solution, the cells were then washed with PBS for three times and further fixed with $1 \%$ citric acid solution for $2 \mathrm{~h}$. Subsequently, the cells was washed with PBS for three times and dehydrated with a gradient ethanol-PBS solution (30\%, $50 \%, 70 \%, 80 \%, 90 \%$ and $95 \%$ ) for 15 min each time, and treated with $100 \%$ ethanol or neat acetone for $20 \mathrm{~min}$, respectively. The cell samples were then treated with a mixture of embedding agent and acetone $(\mathrm{V} / \mathrm{V}=1 / 1)$ for $1 \mathrm{~h}$, a mixture of embedding agent and acetone $(\mathrm{V} / \mathrm{V}=3 / 1)$ for $3 \mathrm{~h}$, and pure embedding agent overnight, and finally embedded and heated at $70{ }^{\circ} \mathrm{C}$ overnight to obtain the embedded sample. The samples were sliced in a LEICA EM UC7 ultrathin slicer to obtain 70-90 nm slices. Eventually, the sections were stained with lead citrate solution and uranyl acetate $50 \%$ ethanol saturated solution for 5-10 min, respectively. The bio-TEM images were recorded by FEI Tecnai Spirit with an accelerating voltage of $80 \mathrm{kV}$, and the EDS was perfomed with an accelerating voltage of $80 \mathrm{KV}$.

\section{Microscale thermophoresis (MST) assays}

Proteins Bcl-xL and Bax were labeled with Monolith NT ${ }^{\text {TM }}$ Protein Labeling Kit RED following the standard protocol provided by the supplier. All the protein samples were diluted by PBS to be a concentration of $208 \mathrm{nM}$ and added with peptide treatments $\mathrm{Py}^{\mathrm{Me}} \mathrm{AmpBC}$ and $\mathrm{BH} 3$ PEP with a concentration ranging from 0.01525 to $125 \mu \mathrm{M}$. After incubation for $30 \mathrm{~min}$ at room temperature, the mixture of labeled proteins and peptide treatments was loaded into Monolith TM standard treated capillaries. The MST measurements were performed at $25^{\circ} \mathrm{C}$ on a Monolith NT.115 instrument. Laser 
power and LED power was set to be $20 \%$ and $100 \%$, respectively. The dissociation constant $\left(\mathrm{K}_{\mathrm{d}}\right)$ values between protein and peptide treatments were obtained using the NT Analysis software.

\section{JC-1 detection of mitochondrial membrane potential}

HeLa cells in DMEM medium were cultured on a confocal glass-bottom plate with a density of $1.2 \times 10^{5}$ overnight. The cells were then treated with $\mathrm{Py}^{\mathrm{Me}} \mathrm{Amp}, \mathrm{BH} 3 \mathrm{PEP}, \mathrm{Py}^{\mathrm{Me}} \mathrm{AmpB}$, free CPT, $\mathrm{Py}^{\mathrm{Me}} \mathrm{AmpC}$, or $\mathrm{Py}^{\mathrm{Me}} \mathrm{AmpBC}$ (dose of CPT moiety: $2.5 \mu \mathrm{M}$, or dose of BH3 domain: $5 \mu \mathrm{M}$ ) for $4 \mathrm{~h}$. After removing the culture solution, the cells were then washed twice with PBS and added $1 \mathrm{~mL}$ JC-1 staining solution $(2.5 \mu \mathrm{g} / \mathrm{mL})$. The cells were incubated at $37^{\circ} \mathrm{C}$ for 30 minutes in a cell culture incubator. Afterwards, the cells were washed with PBS three times and imaged under a fluorescence microscope $(\mathrm{Ex}=488 \mathrm{~nm})$. For flow cytometric experiments, HeLa cells were cultured for $24 \mathrm{~h}$ in 6-well plates with a density of $1 \times 10^{6}$ cells per well and incubated at $37^{\circ} \mathrm{C}$ for $24 \mathrm{~h}$. The cells were then incubated in the presence of $\mathrm{Py}^{\mathrm{Me}}$ Amp, BH3 PEP, $\mathrm{Py}^{\mathrm{Me}} \mathrm{AmpB}$, free $\mathrm{CPT}, \mathrm{Py}^{\mathrm{Me}} \mathrm{AmpC}$, or $\mathrm{Py}^{\mathrm{Me}} \mathrm{AmpBC}$ (dose of CPT moiety: $2.5 \mu \mathrm{M}$, or dose of BH3 domain: $5 \mu \mathrm{M}$ ) for $4 \mathrm{~h}$. The cells were then trypsinized and collected. After thoroughly washing with PBS and resuspending by $0.5 \mathrm{~mL}$ JC-1 staining solution, the cells were further incubated at $37^{\circ} \mathrm{C}$ for another 30 minutes and then centrifugated at $1500 \mathrm{r} / \mathrm{min}$ for $3 \mathrm{~min}$. Removing the supernatant and washing twice with PBS yielded the cell samples following resuspending in $0.5 \mathrm{~mL}$ of PBS. The cells were measured by flow cytometer (BD LSR Fortessa, USA).

\section{Weston blot studies}

HeLa cells were cultured in $10 \mathrm{~cm}^{2}$ cell culture dish (polyethylene plastic) with a density of $2 \times 10^{6}$ in DMEM medium and incubated overnight. The culture medium was replaced by fresh culture medium 
containing Py ${ }^{\mathrm{Me}} \mathrm{Amp}, \mathrm{Py}^{\mathrm{Me}} \mathrm{AmpB}, \mathrm{Py}^{\mathrm{Me}} \mathrm{AmpC}$, or $\mathrm{Py}^{\mathrm{Me}} \mathrm{AmpBC}$ (dose of CPT moiety: $2.5 \mu \mathrm{M}$, or dose of BH3 domain: $5 \mu \mathrm{M}$ ). After $24 \mathrm{~h}$, the cells were collected and resuspended with PBS buffer. For estimating the protein expression of cytochrome $\mathrm{c}$ in cytosol or cytochrome $\mathrm{c}$, Bax, and Bcl-xL in mitochondria, the mitochondria were isolated using Cell Mitochondria Isolation Kit (Beyotime Biotechnology) following the standard protocol provided by the supplier. After measuring the concentrations of the proteins by Bradford Protein Quantitative Detection kit (Sangon Biotechnology), the proteins were incubated with loading buffer at $100^{\circ} \mathrm{C}$ for 10 minutes. Subsequently, an equal amount of proteins from each sample $(25 \mu \mathrm{g})$ were loaded to SDS-PAGE gels (Tris-Gly, 4-20 \%) and electrophoretically transferred to polyvinylidene difluoride membranes (PVDF). The membranes were blocked with $5 \%$ non-fat milk at room temperature for $1 \mathrm{~h}$ and then incubated with the respective specific primary antibody at $4{ }^{\circ} \mathrm{C}$ overnight. After incubating with horseradish peroxidase conjugated secondary antibody at room temperature for $1 \mathrm{~h}$, the protein bands were imaged with ECL chemiluminescence detection kit using a Tanon-5200Multi instrument.

\section{Caspase-9 or caspase-3 activity assay}

HeLa cells were cultured in 96 -well plates with a density of $5 \times 10^{3}$ in DMEM medium and incubated overnight. The culture medium was replaced by fresh culture medium containing PBS, $\mathrm{Py}^{\mathrm{Me}} \mathrm{Amp}, \mathrm{BH} 3$ PEP, Py ${ }^{\mathrm{Me}} \mathrm{AmpB}$, free $\mathrm{CPT}, \mathrm{Py}^{\mathrm{Me}} \mathrm{AmpC}$, or $\mathrm{Py}^{\mathrm{Me}} \mathrm{AmpBC}$ (dose of CPT moiety: $2.5 \mu \mathrm{M}$, or dose of BH3 domain: $5 \mu \mathrm{M}$ ). After $12 \mathrm{~h}$, the cells were collected and washed with PBS. After centrifuging and re-suspending in lysis buffer for $15 \mathrm{~min}$ on ice, the cells were collected by centrifugation for $15 \mathrm{~min}$ at $4{ }^{\circ} \mathrm{C}$. Eventually, $40 \mu \mathrm{L}$ of the supernatant was added to a 96 -well plate and incubated with $10 \mu \mathrm{L}$ of Ac-LEHD-pNA / Ac-DEVD-pNA $(2 \mathrm{mM})$ buffer solution for $1 \mathrm{~h}$ at $37^{\circ} \mathrm{C}$. The caspase- 9 or 
caspase-3 activity was determined by recording the absorption intensity at $405 \mathrm{~nm}$ via a microplate reader (TECAN Infinite M Nano).

\section{In vivo and ex vivo imaging}

Female BALB/c nude mice (6-8 weeks) were purchased from Charles River Laboratory Animal Technology Co., Ltd. and all the in vivo experiments were carried out following the protocols approved by the Animal Care and Use Committee of the Nankai University. The tumor models were established by subcutaneously injecting HeLa cells $\left(1 \times 10^{6}\right)$ into BALB/c nude mice. Seven days after cell inoculation, the tumor-bearing mice were weighed and casually divided into six groups $(n=3)$. Then different treatments $\mathrm{Py}^{\mathrm{Me}} \mathrm{Amp}, \mathrm{BH} 3 \mathrm{PEP}, \mathrm{Py}^{\mathrm{Me}} \mathrm{AmpB}, \mathrm{Py}^{\mathrm{Me}} \mathrm{AmpC}$, and $\mathrm{Py}^{\mathrm{Me}} \mathrm{AmpBC}$ containing the corresponding FAM-labeled peptide (a dose of $10 \mu \mathrm{M}$ for FAM moiety) were intravenously injected into the mice. At the predetermined time post-injection $(2,4,8,12,24$, and $36 \mathrm{~h})$, the bioluminescence were detected by IVIS Lumina system. At 36 h, animals are sacrificed, and major organs (heart, liver, spleen, lung, kidney) and tumors were collected for ex vivo imaging and analysis.

\section{In vivo tumor therapy}

When the volume of the tumor reached $100 \mathrm{~mm}^{3}$, the HeLa tumor-bearing mice were randomly divided into 6 groups for different treatments (n=5): (1) PBS, (2) $\left.\left.\left.\mathrm{Py}^{\mathrm{Me}} \mathrm{Amp}, 3\right) \mathrm{BH} 3 \mathrm{PEP}, 4\right) \mathrm{Py}^{\mathrm{Me}} \mathrm{AmpB}, 5\right)$ free CPT, 6) $\mathrm{Py}^{\mathrm{Me}} \mathrm{AmpC}$, and 7) $\mathrm{Py}^{\mathrm{Me}} \mathrm{AmpBC}$. All the tumor-bearing mice were intravenously injected with $200 \mu \mathrm{L}$ of PBS, Py ${ }^{\mathrm{Me}} \mathrm{Amp}$, BH3 PEP, $\mathrm{Py}^{\mathrm{Me}} \mathrm{AmpB}$, free CPT, $\mathrm{Py}^{\mathrm{Me}} \mathrm{AmpB}$, or $\mathrm{Py}^{\mathrm{Me}} \mathrm{AmpBC}$, with a dose of $20 \mathrm{mg} / \mathrm{kg}$ for BH3 PEP moiety or with a dose of $2 \mathrm{mg} / \mathrm{kg}$ for CPT moiety at day 1 , day 3 and day 5. The body weight and the tumor size of each mouse were monitored every other day. The tumor 
volume $(V)$ was calculated by the equation: Tumor volume $\left(\mathrm{mm}^{3}\right)=1 / 2 \times$ length $\times$ width ${ }^{2}$ (length is the longer dimension and width is the shorter dimension). The tumors and main organs (heart, liver, spleen, lung and kidney) were collected for the H\&E staining. The H\&E staining images were imaged by OLYMPUS CKX53. All of the animal experiments were carried out under the approved protocols of the Institutional Animal Care. 

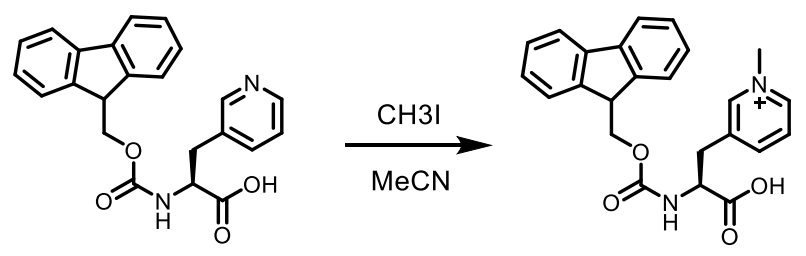

Figure S1. Synthetic route for Fmoc-L-3-(3-methylpyridyl)-alanine.

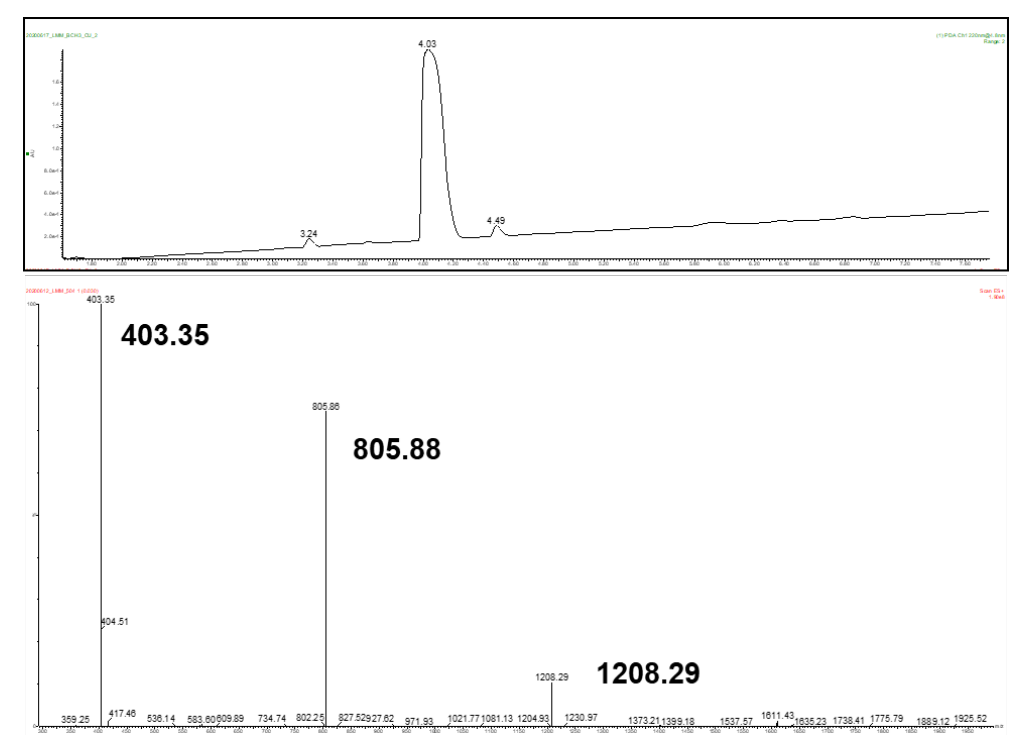

Figure S2. UPLC trace (top) and mass spectrum (bottom) of Fmoc-L-3-(3-methylpyridyl)-alanine. 

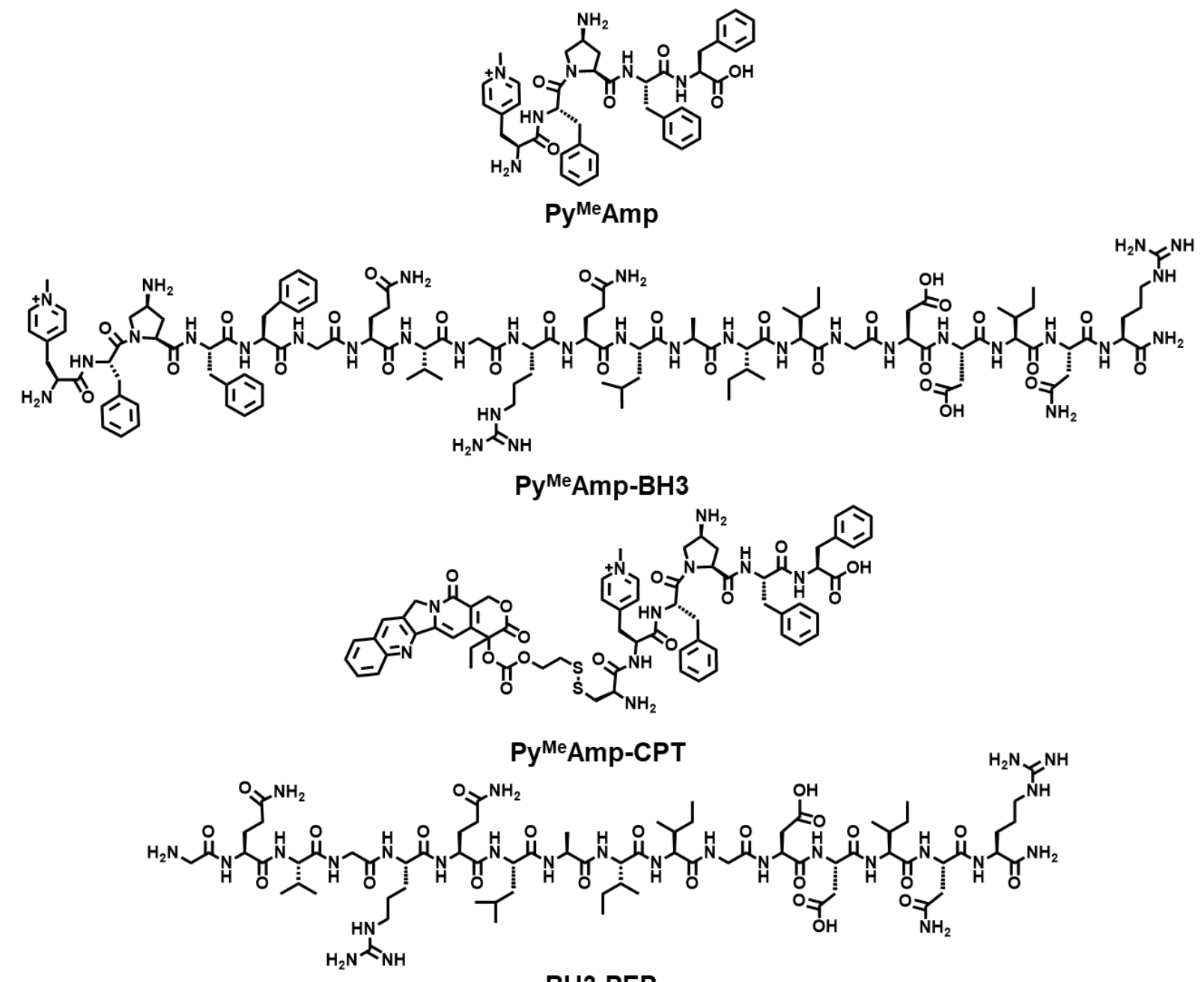

BH3 PEP

Figure S3. Chemical structures of peptides $\mathrm{Py}^{\mathrm{Me}} \mathrm{Amp}, \mathrm{Py}^{\mathrm{Me}} \mathrm{Amp}-\mathrm{CPT}, \mathrm{Py}^{\mathrm{Me}} \mathrm{Amp}-\mathrm{BH}$, and BH3 PEP.

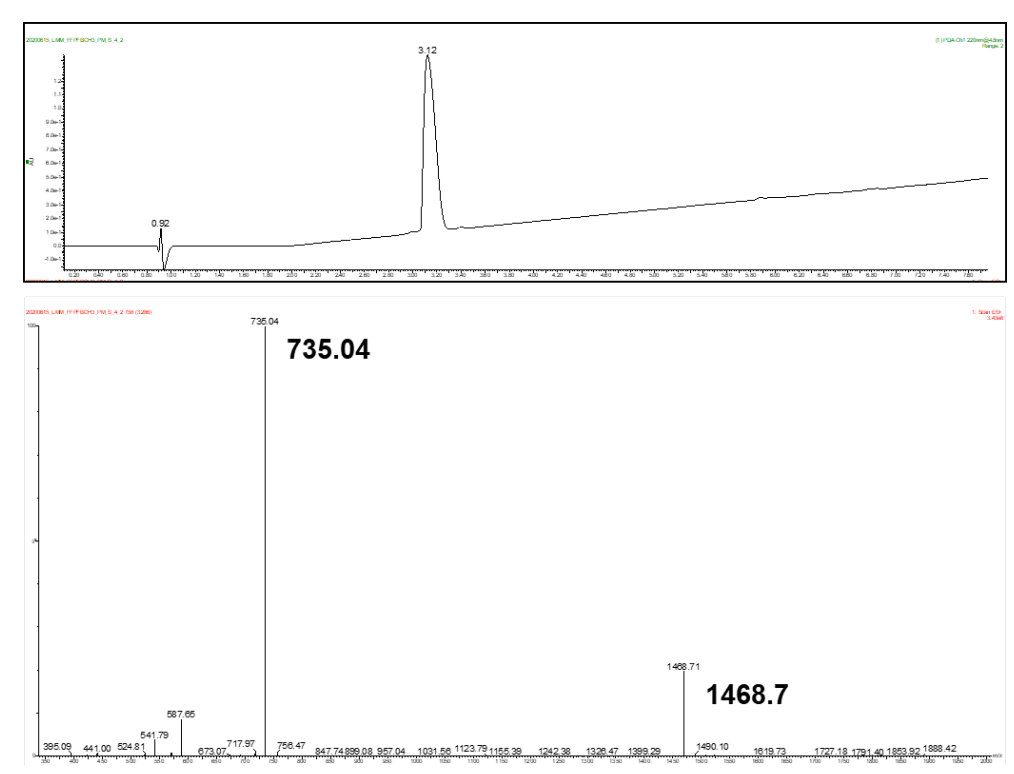

Figure S4. UPLC trace (top) and mass spectrum (bottom) of peptide $\mathrm{Py}^{\mathrm{Me}} \mathrm{Amp}$. 


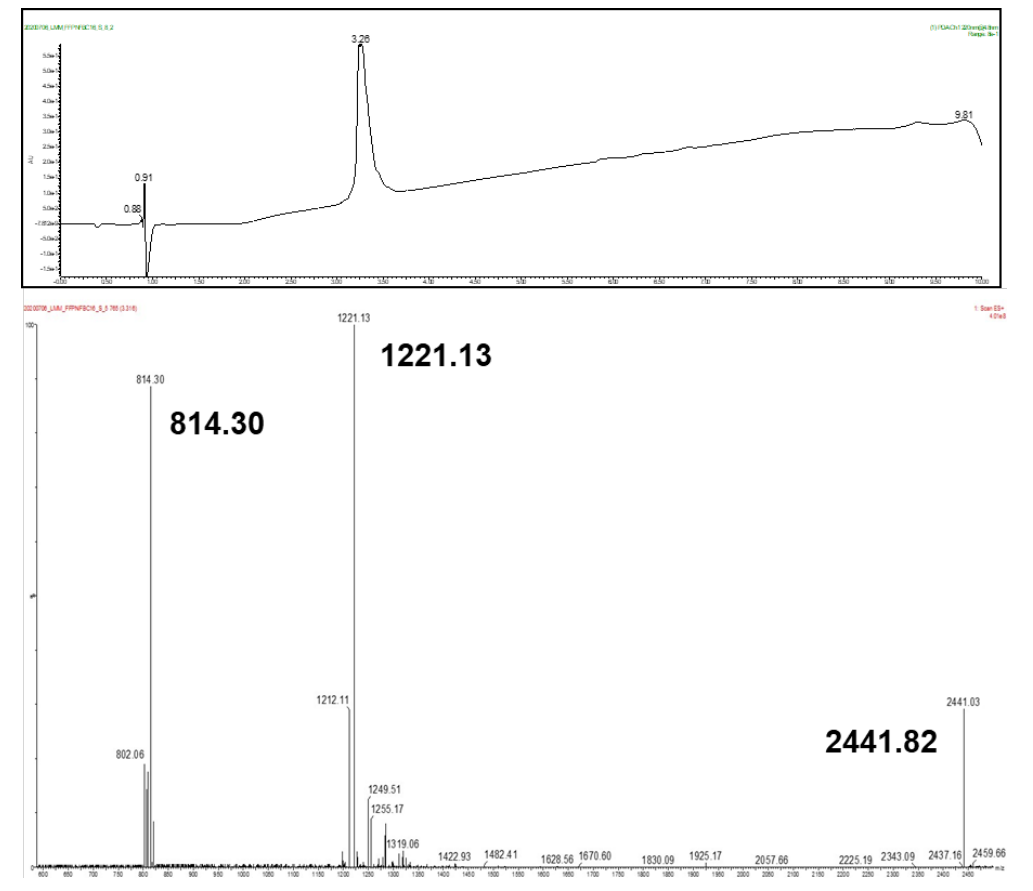

Figure S5. UPLC trace (top) and mass spectrum (bottom) of peptide $\mathrm{Py}^{\mathrm{Me}} \mathrm{Amp}-\mathrm{BH} 3$.

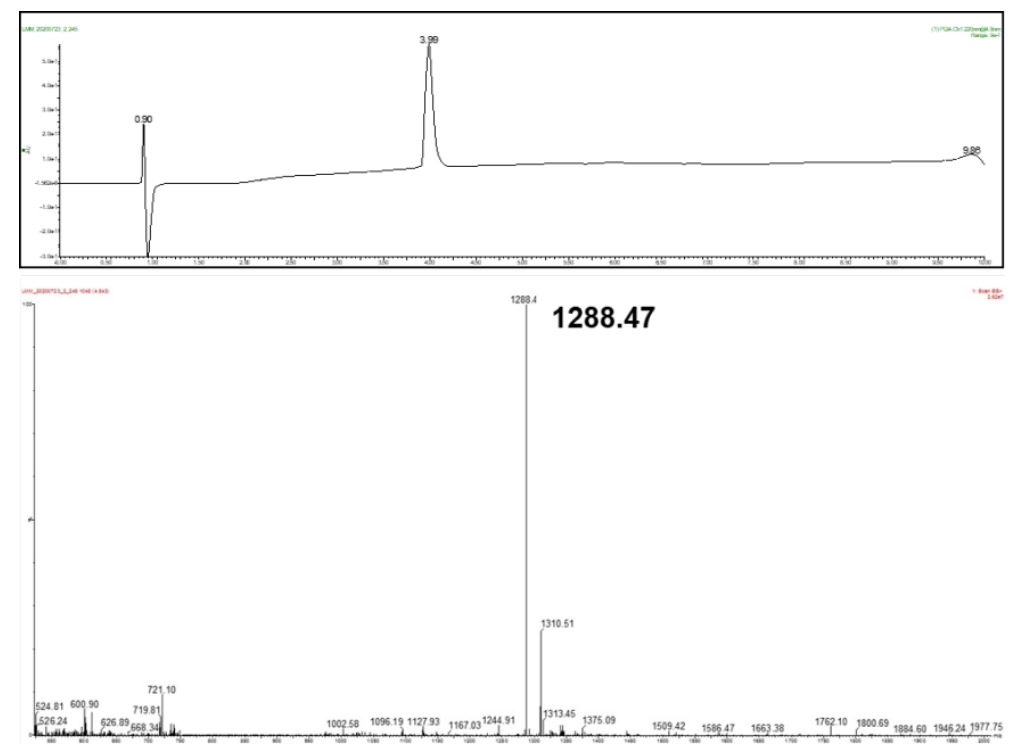

Figure S6. UPLC trace (top) and mass spectrum (bottom) of peptide $\mathrm{Py}^{\mathrm{Me}} \mathrm{Amp}-\mathrm{CPT}$. 


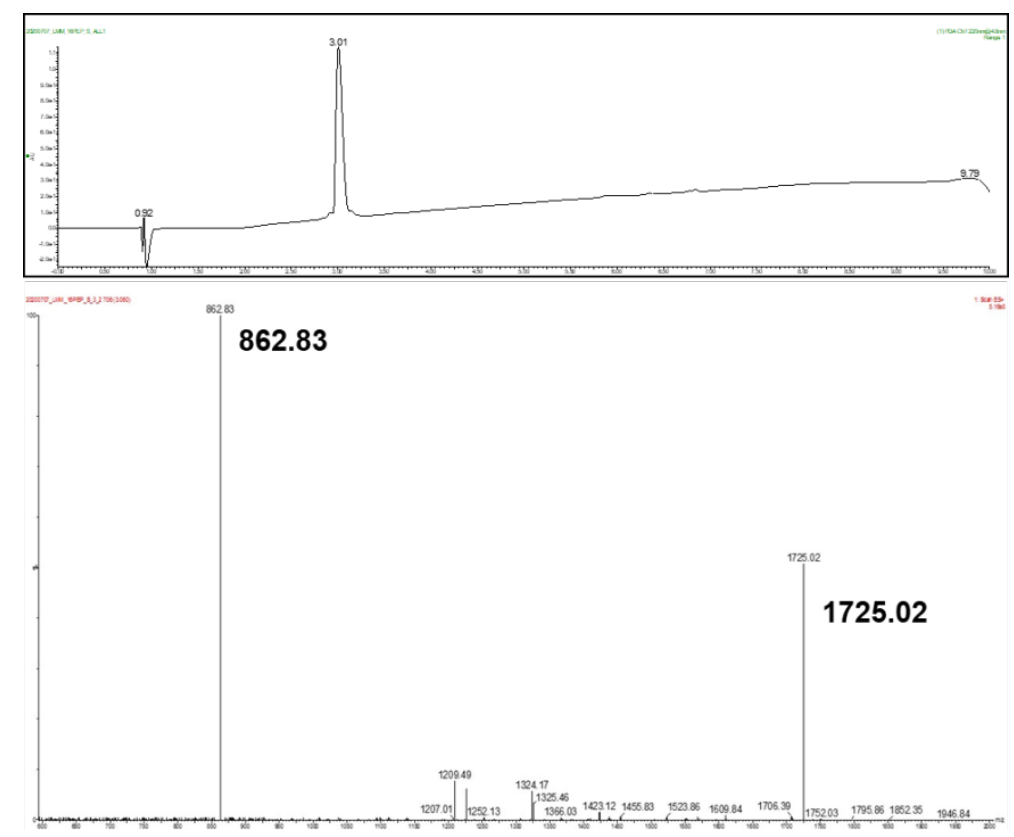

Figure S7. UPLC trace (top) and mass spectrum (bottom) of BH3 PEP.

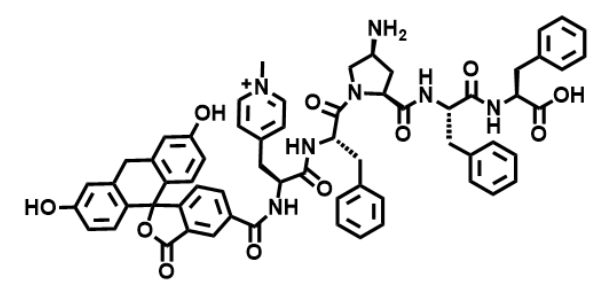

PyMeAmp-FAM

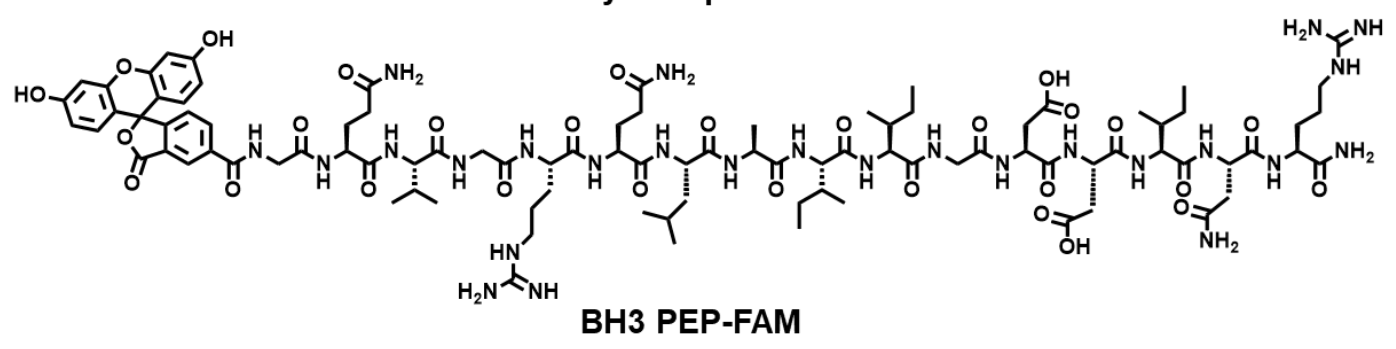

Figure S8. Chemical structures of peptides $\mathrm{Py}^{\mathrm{Me}}$ Amp-FAM and BH3 PEP-FAM. 


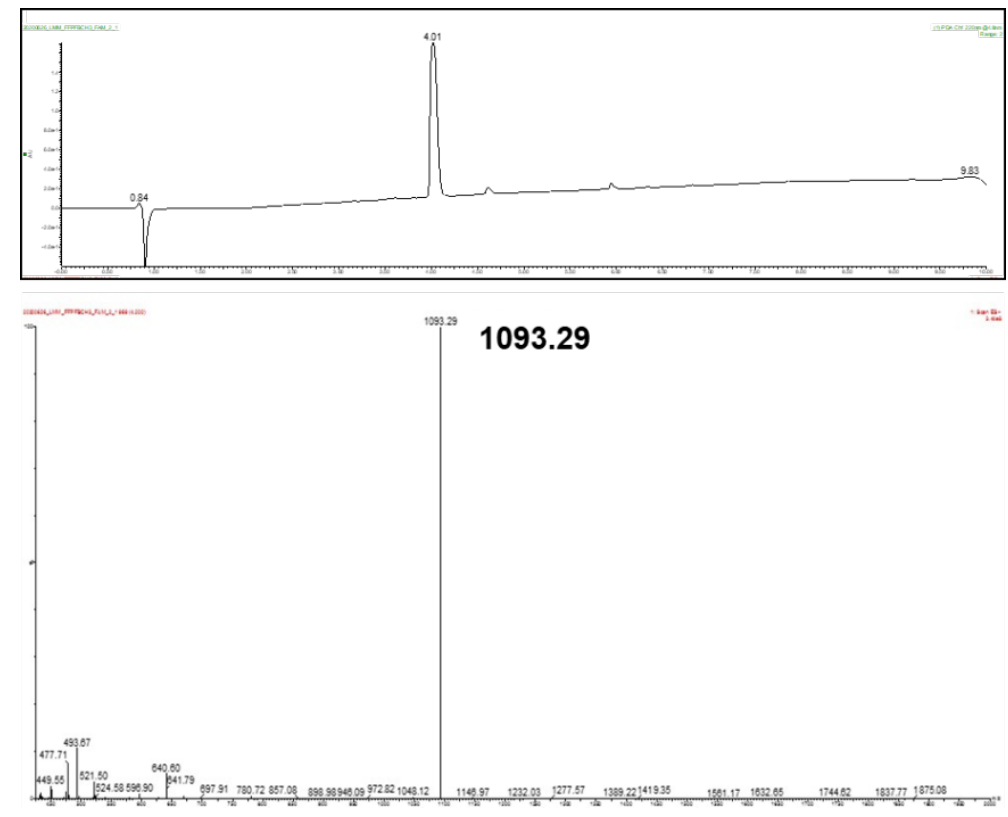

Figure S9. UPLC trace (top) and mass spectrum (bottom) of peptide $\mathrm{Py}^{\mathrm{Me}} \mathrm{Amp}-\mathrm{FAM}$.
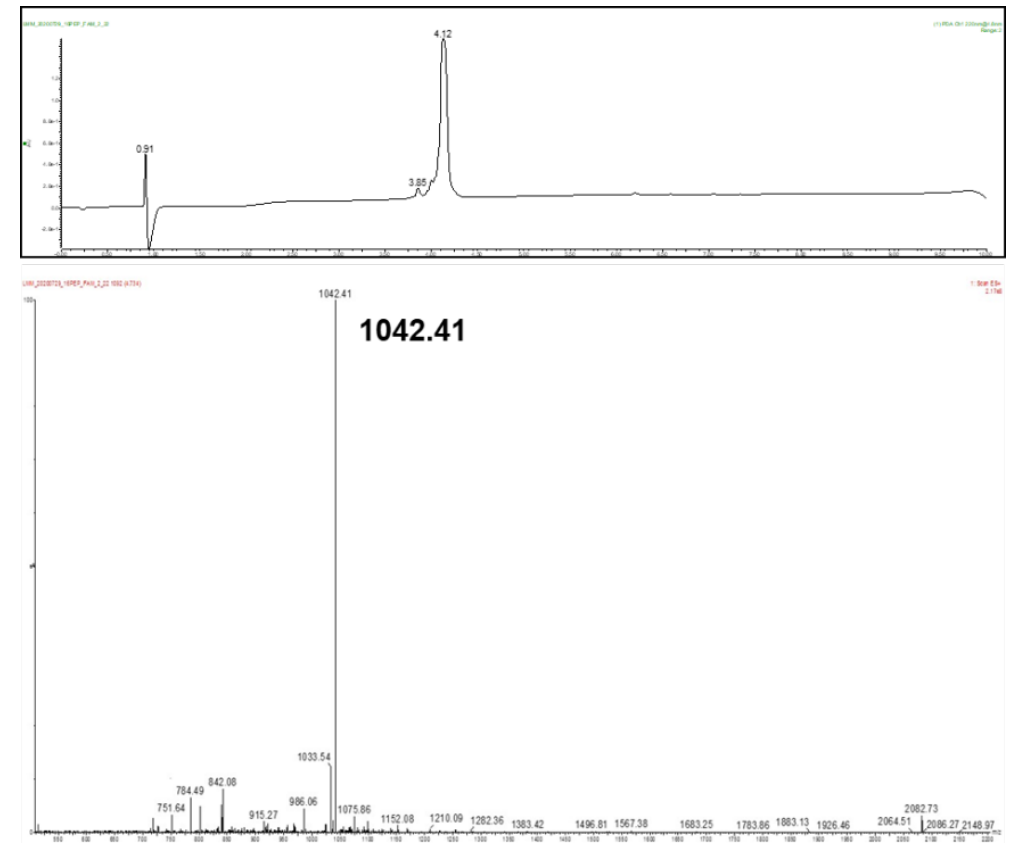

Figure S10. UPLC trace (top) and mass spectrum (bottom) of BH3 PEP-FAM. 


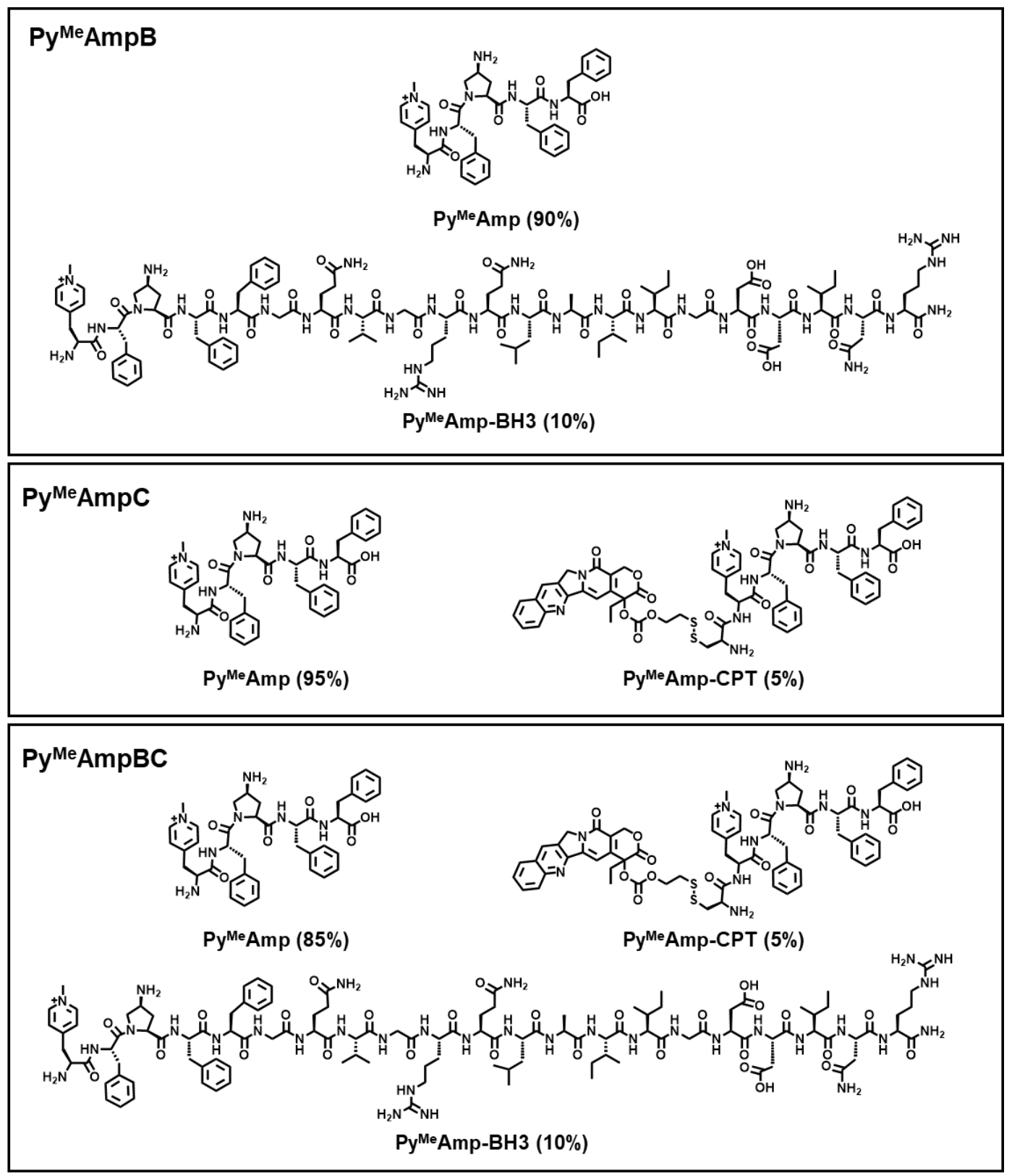

Figure S11. Schematic illustration of the components of chemodrugs $\mathrm{Py}^{\mathrm{Me}} \mathrm{AmpB}$ (top), $\mathrm{Py}^{\mathrm{Me}} \mathrm{AmpC}$ (center), and $\mathrm{Py}^{\mathrm{Me}} \mathrm{AmpBC}$ (bottom). 


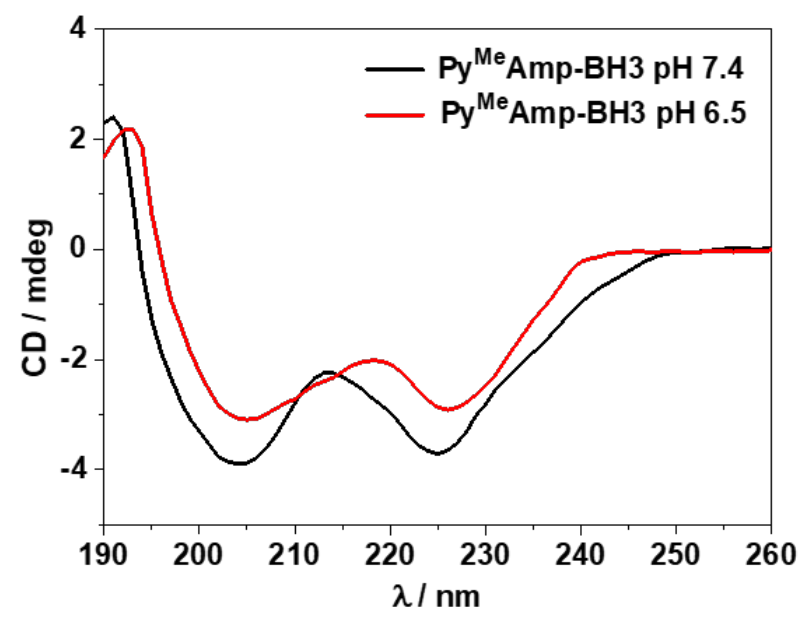

Figure S12. CD spectra of peptide $\mathrm{Py}^{\mathrm{Me}} \mathrm{Amp}-\mathrm{BH} 3$ at $\mathrm{pH} 7.4$ and 6.5.

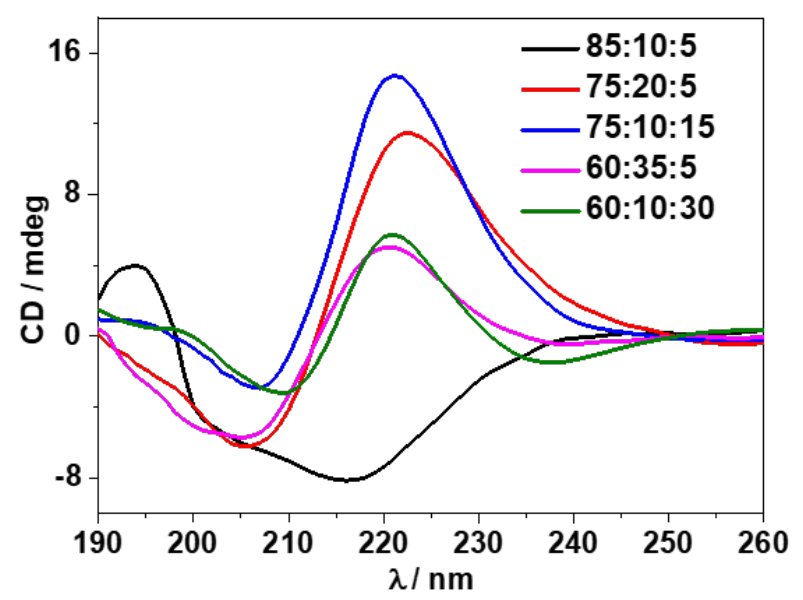

Figure S13. CD spectra of coassemblies of $\mathrm{Py}^{\mathrm{Me}} \mathrm{Amp}, \mathrm{Py}^{\mathrm{Me}} \mathrm{Amp}-\mathrm{BH} 3$, and $\mathrm{Py}^{\mathrm{Me}} \mathrm{Amp}-\mathrm{CPT}$ with various molar ratios at $\mathrm{pH}$ 7.4. CD spectra of the coassemblies with a lowered content of $\mathrm{Py}^{\mathrm{Me}} \mathrm{Amp}$ did not show the conventional $\mathrm{CD}$ signals for $\beta$-sheets at $\mathrm{pH} 7.4$, indicating the interrupted formation of well-defined secondary structures and nanostructures via increasing the functionalized counterparts. 


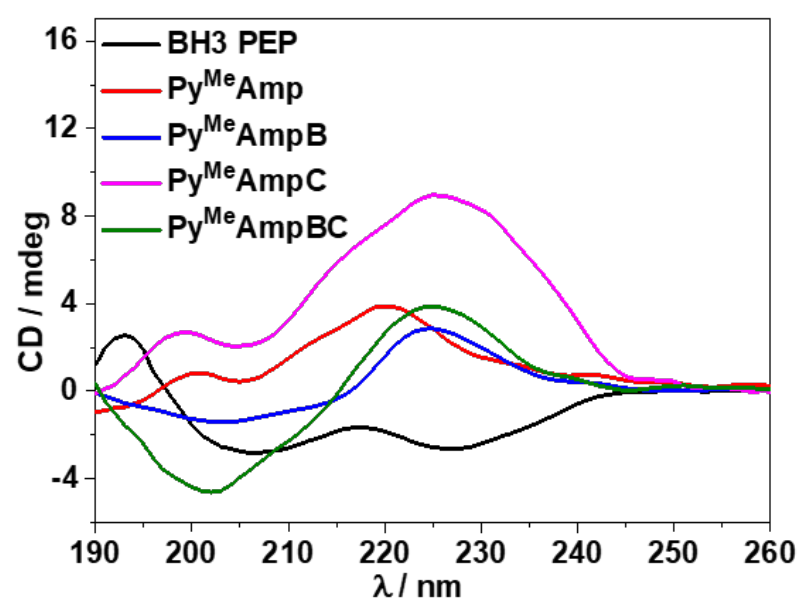

Figure S14. CD spectra of $\mathrm{Py}^{\mathrm{Me}} \mathrm{Amp}, \mathrm{BH} 3 \mathrm{PEP}, \mathrm{Py}^{\mathrm{Me}} \mathrm{AmpB}, \mathrm{Py}^{\mathrm{Me}} \mathrm{AmpC}$, and $\mathrm{Py}^{\mathrm{Me}} \mathrm{AmpBC}$ at pH 6.5.
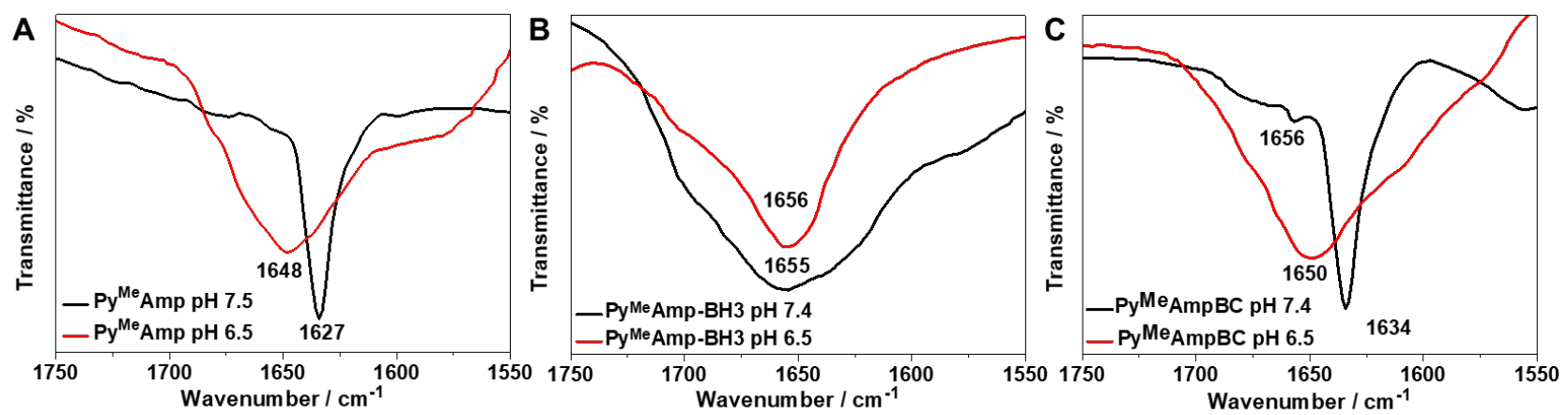

Figure S15. FTIR spectra of (A) peptide $\mathrm{Py}^{\mathrm{Me}} \mathrm{Amp}$, (B) $\mathrm{Py}^{\mathrm{Me}} \mathrm{Amp}-\mathrm{BH}$, and (C) $\mathrm{Py}^{\mathrm{Me}} \mathrm{AmpBC}$ at $\mathrm{pH}$ 7.4 and 6.5. FTIR spectra of peptide $\mathrm{Py}^{\mathrm{Me}} \mathrm{Amp}$ and coassembly $\mathrm{Py}^{\mathrm{Me}} \mathrm{AmpBC}$ displayed a predominate peak at approximately 1630 and $1650 \mathrm{~cm}^{-1}$ at $\mathrm{pH} 7.4$ and 6.5 , respectively, indicating formation of $\beta$ sheets and random coils at pH 7.4 and 6.5. However, the spectra of peptide $\mathrm{Py}^{\mathrm{Me}} \mathrm{Amp}-\mathrm{BH} 3$ showed a strong band at ca. $1655 \mathrm{~cm}^{-1}$ at both $\mathrm{pH} 7.4$ and 6.5, suggesting adopting $\alpha$-helical conformation independent on the solution $\mathrm{pH}$. These results are consistent with those of CD studies. 

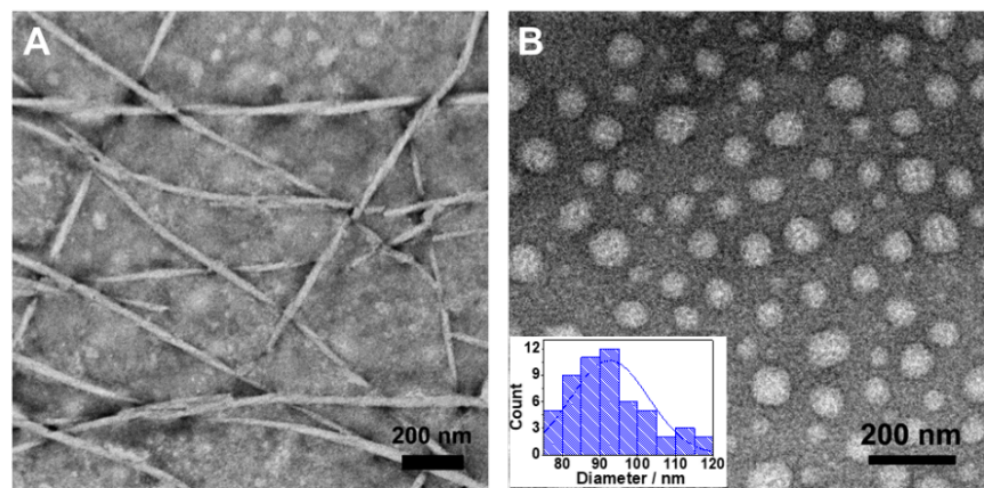

Figure S16. TEM images of peptide $\mathrm{Py}^{\mathrm{Me}} \mathrm{Amp}$ at $\mathrm{pH} 7.4$ (A) and 6.5 (B). The size distribution of the nanoparticles formed by $\mathrm{Py}^{\mathrm{Me}} \mathrm{Amp}$ at $\mathrm{pH} 6.5$ as shown in the inset panel of (B).
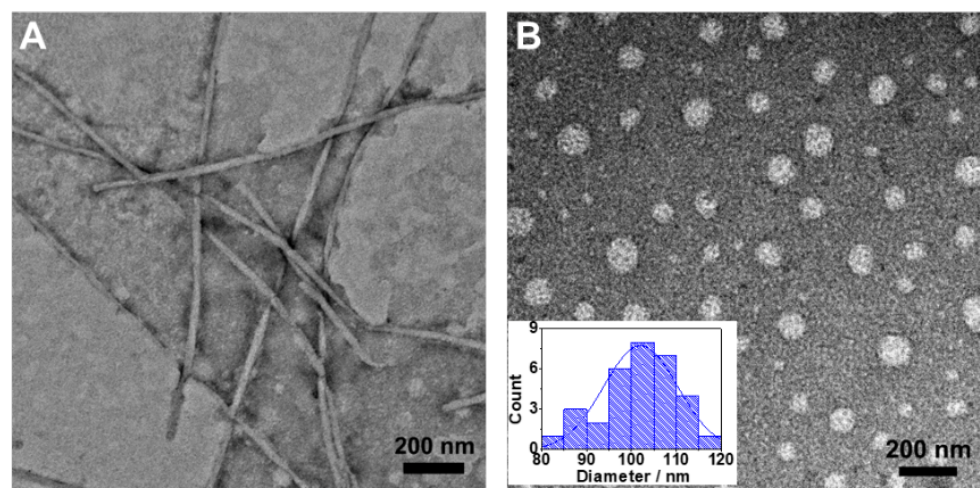

Figure S17. TEM images of $\mathrm{Py}^{\mathrm{Me}} \mathrm{AmpBC}$ at $\mathrm{pH} 7.4$ (A) and 6.5 (B). The size distribution of the nanoparticles formed by $\mathrm{Py}^{\mathrm{Me}} \mathrm{AmpBC}$ at $\mathrm{pH} 6.5$ as shown in the inset panel of (B).
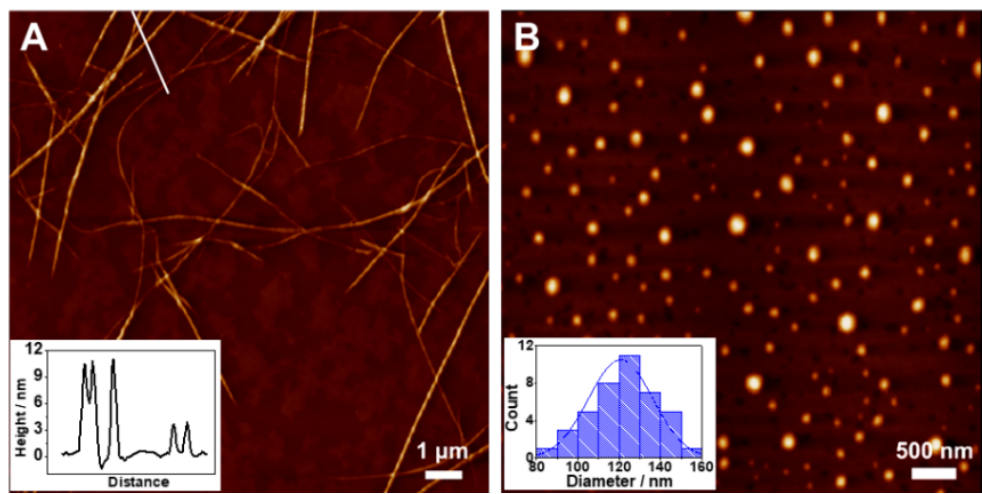

Figure S18. (A) AFM image and the corresponding height profile of the single fiber and the superhelices of $\mathrm{Py}^{\mathrm{Me}} \mathrm{AmpB}$ at $\mathrm{pH}$ 7.4. (B) AFM image and the size distribution of the nanoparticles formed by $\mathrm{Py}^{\mathrm{Me}} \mathrm{AmpB}$ at $\mathrm{pH} 6.5$. 

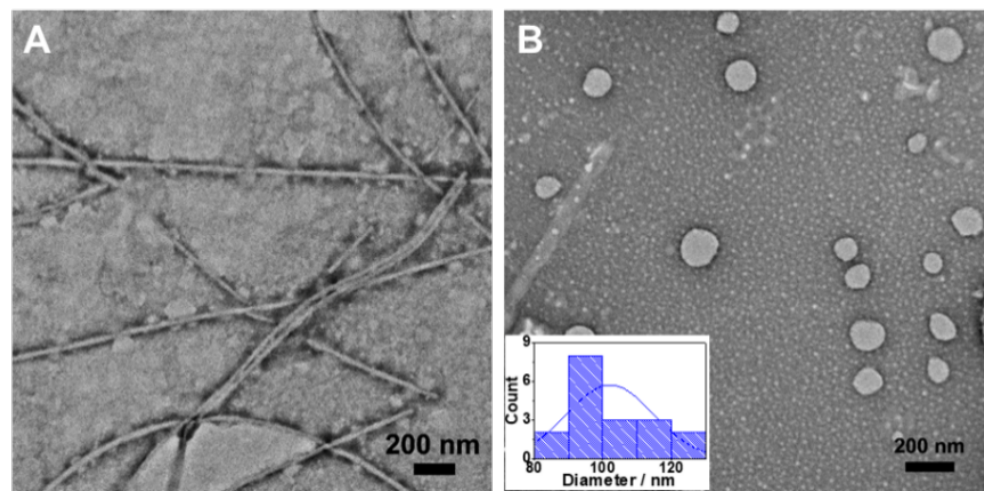

Figure S19. TEM images of $\mathrm{Py}^{\mathrm{Me}} \mathrm{AmpB}$ at $\mathrm{pH} 7.4$ (A) and 6.5 (B). The size distribution of the nanoparticles formed by $\mathrm{Py}^{\mathrm{Me}} \mathrm{AmpB}$ at $\mathrm{pH} 6.5$ as shown in the inset panel of (B).
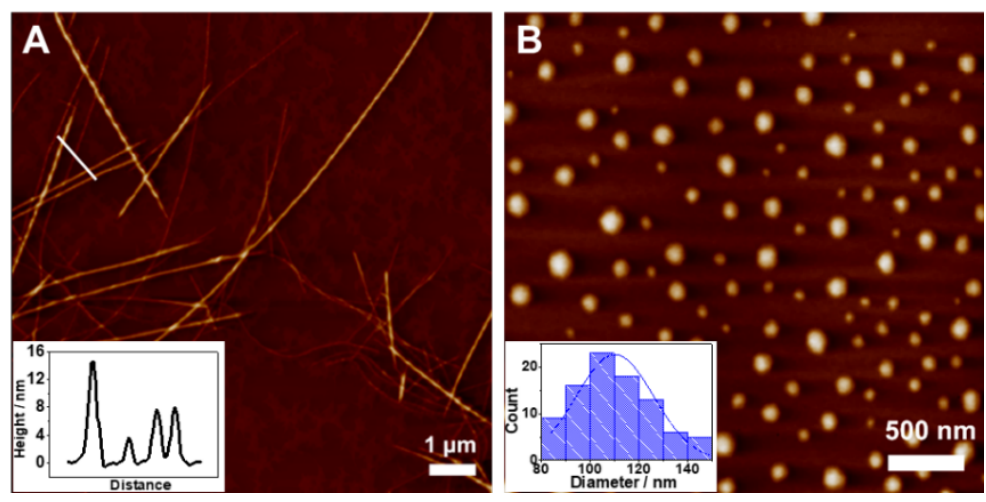

Figure S20. (A) AFM image and the corresponding height profile of the single fiber and the superhelices of $\mathrm{Py}^{\mathrm{Me}} \mathrm{AmpC}$ at $\mathrm{pH}$ 7.4. (B) AFM image and the size distribution of the nanoparticles formed by $\mathrm{Py}^{\mathrm{Me}} \mathrm{AmpC}$ at $\mathrm{pH} 6.5$.
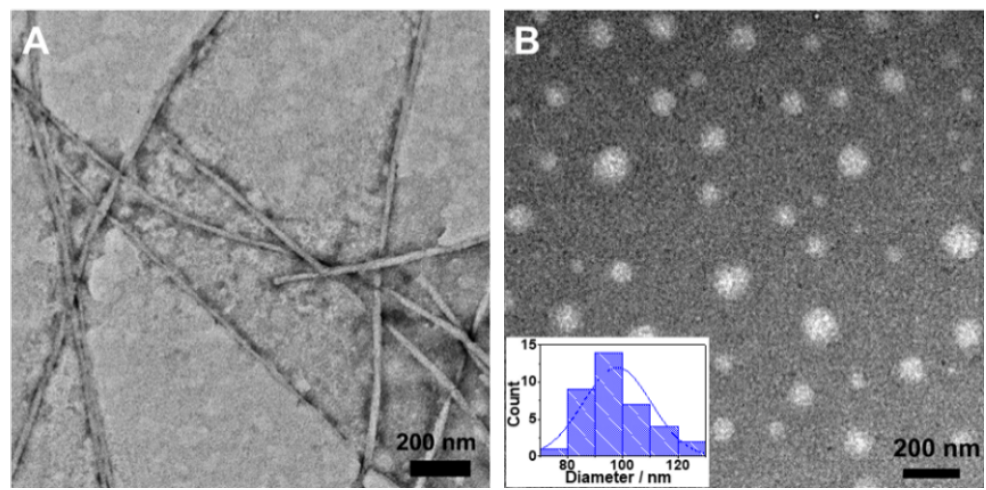

Figure S21. TEM images of $\mathrm{Py}^{\mathrm{Me}} \mathrm{AmpC}$ at $\mathrm{pH} 7.4$ (A) and 6.5 (B), respectively. The size distribution of the nanoparticles formed by $\mathrm{Py}^{\mathrm{Me}} \mathrm{AmpC}$ at $\mathrm{pH} 6.5$ as shown in the inset panel of (B). 

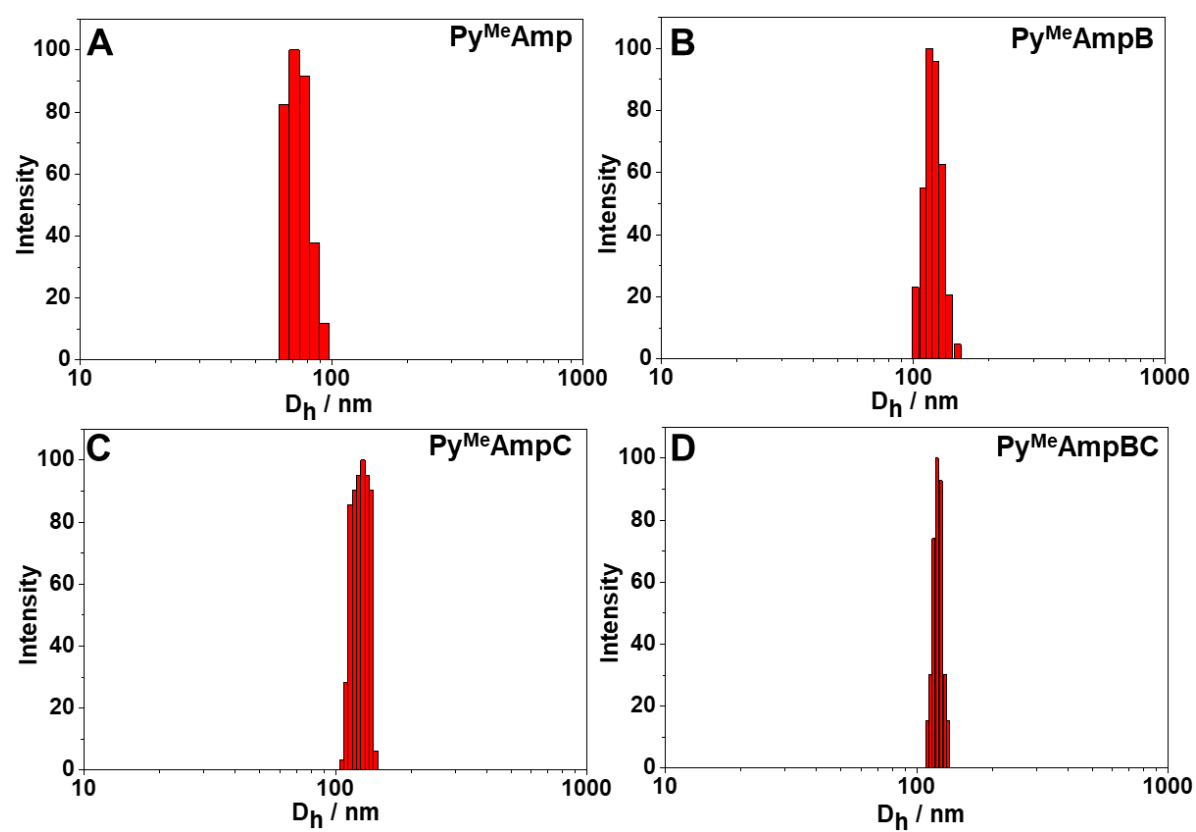

Figure S22. Hydrodynamic size of $\mathrm{Py}^{\mathrm{Me}} \mathrm{Amp}(\mathrm{A}), \mathrm{Py}^{\mathrm{Me}} \mathrm{AmpB}(\mathrm{B}), \mathrm{Py}^{\mathrm{Me}} \mathrm{AmpC}(\mathrm{C})$, and $\mathrm{Py}{ }^{\mathrm{Me}} \mathrm{AmpBC}$ (D) determined by DLS.
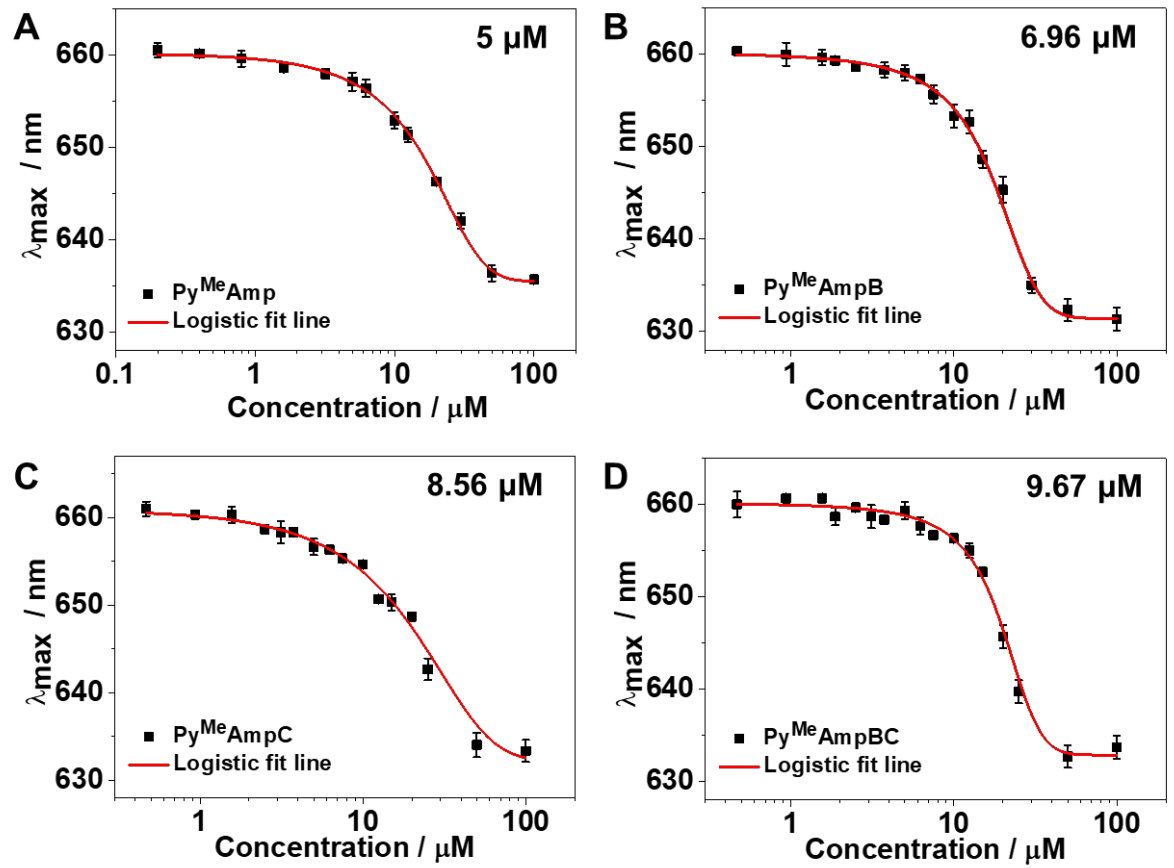

Figure S23. The wavelength of the maximal emission $\left(\lambda_{\max }\right)$ of Nile Red in the presence of Py ${ }^{\mathrm{Me}} \mathrm{Amp}$, $\mathrm{Py}^{\mathrm{Me}} \mathrm{AmpB}, \mathrm{Py}^{\mathrm{Me}} \mathrm{AmpC}$, and $\mathrm{Py}^{\mathrm{Me}} \mathrm{AmpBC}$ as a function of peptide concentration. Based on the plotted emission curve, $\mathrm{Py}^{\mathrm{Me}} \mathrm{Amp}, \mathrm{Py}^{\mathrm{Me}} \mathrm{AmpB}, \mathrm{Py}^{\mathrm{Me}} \mathrm{AmpC}$, and $\mathrm{Py}^{\mathrm{Me}} \mathrm{AmpBC}$ start to aggregate below the concentration of $5 \mu \mathrm{M}, 6.96 \mu \mathrm{M}, 8.56 \mu \mathrm{M}$, and $9.67 \mu \mathrm{M}$, respectively. 

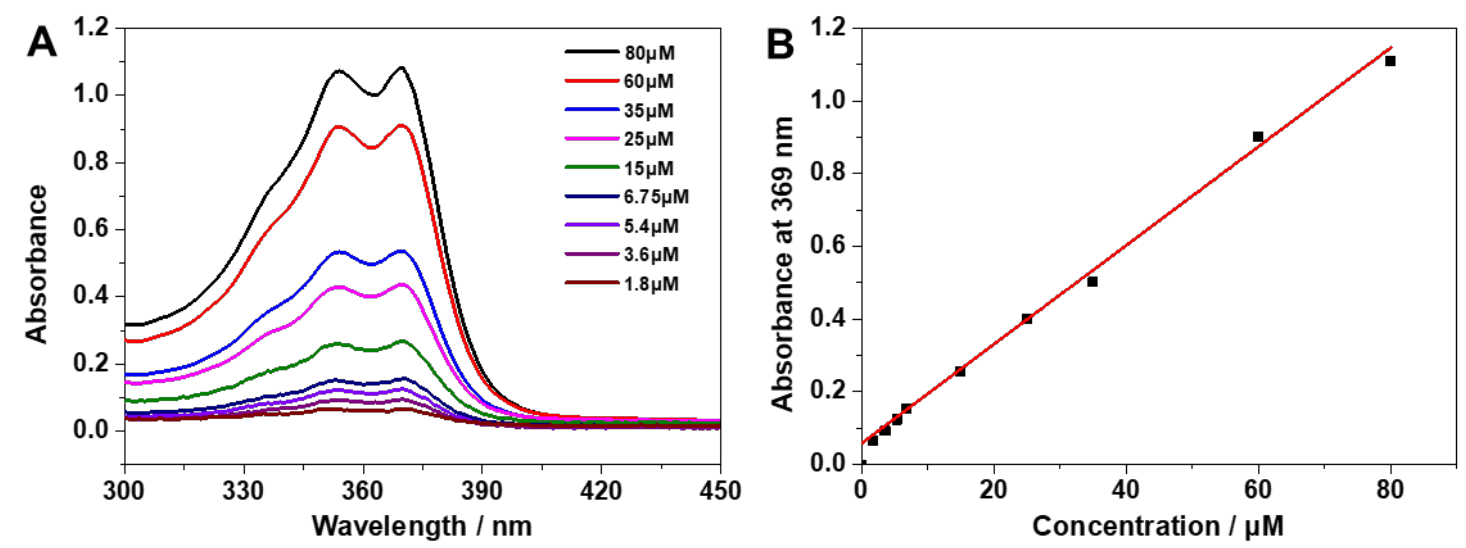

Figure S24. (A) UV/vis absorption spectra of $\mathrm{Py}^{\mathrm{Me}} \mathrm{Amp}-\mathrm{CPT}$ at different concentrations. (B) Standard curve of $\mathrm{Py}^{\mathrm{Me}} \mathrm{Amp}-\mathrm{CPT}$ depicting the absorption intensity at $369 \mathrm{~nm}$, which showed a linear relationship between the absorption intensity and peptide concentration.
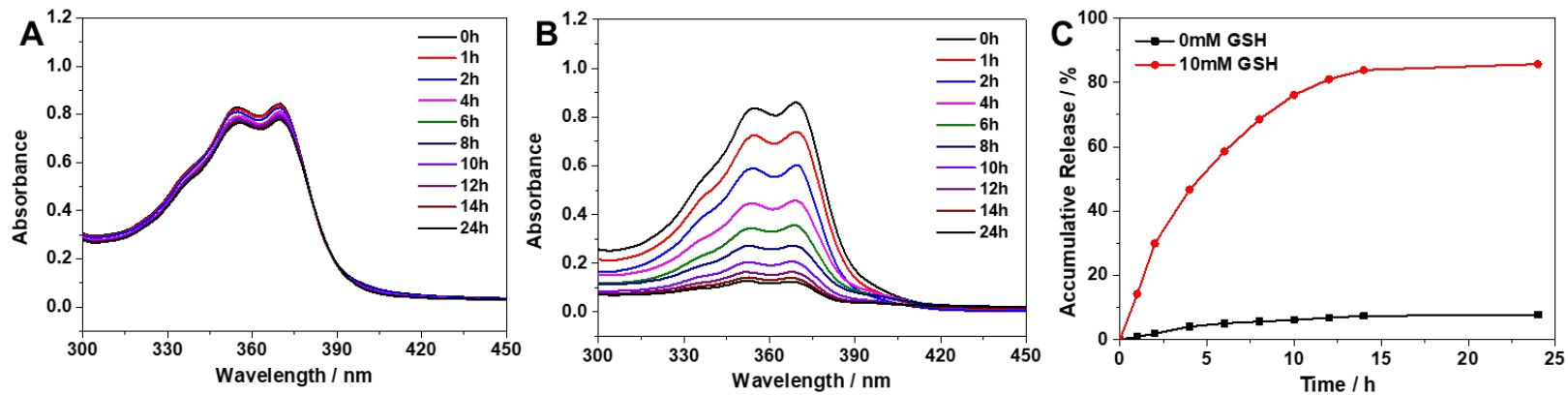

Figure S25. UV/vis absorption spectra of $\mathrm{Py}^{\mathrm{Me}} \mathrm{AmpBC}$ in the presence of GSH with a concentration of (A) $0 \mathrm{mM}$ or (B) $10 \mathrm{mM}$. (C) CPT release profiles induced by $0 \mathrm{mM}$ or $10 \mathrm{mM}$ GSH as a function of time. Addition of GSH into coassembly $\mathrm{Py}^{\mathrm{Me}} \mathrm{AmpBC}$ led to gradual release of CPT over $80 \%$ within 5 hours via reduction of the disulfide bonds, whereas negligible free CPT was detected in the absence of GSH. This result demonstrates the efficient GSH-induced CPT release from $\mathrm{Py}^{\mathrm{Me}} \mathrm{AmpBC}$. It is worth noting that the nanofibril morphology was maintained for $\mathrm{Py}^{\mathrm{Me}} \mathrm{AmpBC}$ once releasing CPT moiety (Figure S25), which potentially contributes to the retention of the remained coassemblies in tumor cells. 

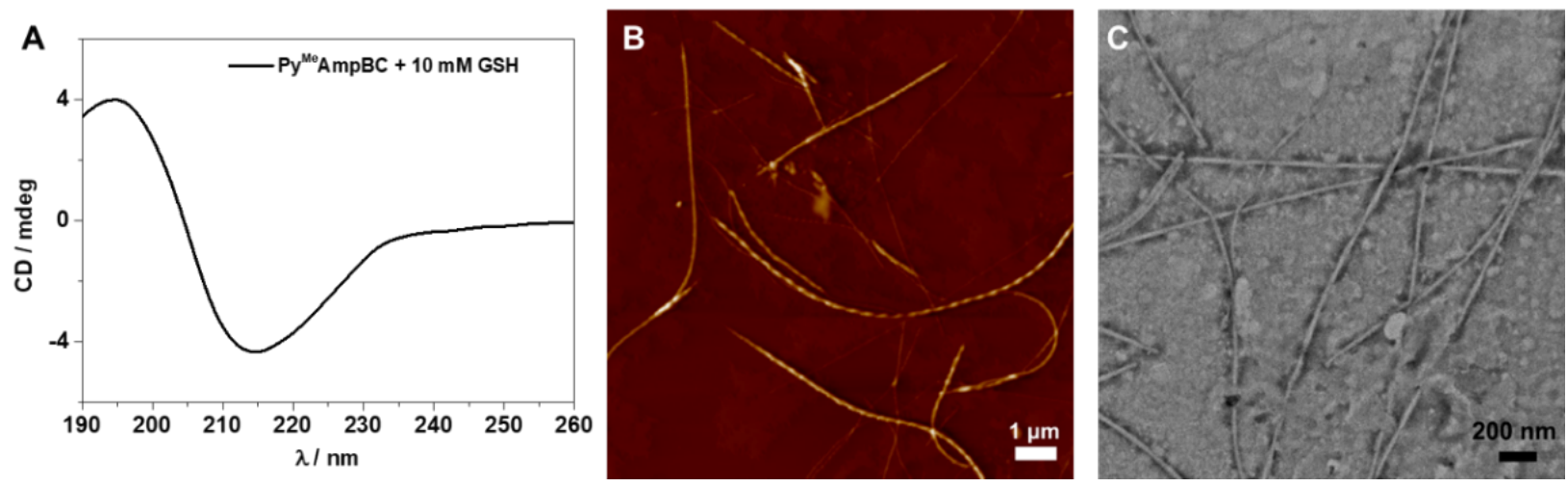

Figure S26. (A) CD spectrum of $\mathrm{Py}^{\mathrm{Me}} \mathrm{AmpBC}$ treated with $10 \mathrm{mM}$ GSH for $24 \mathrm{~h}$. AFM (B) and TEM images (B) of $\mathrm{Py}^{\mathrm{Me}} \mathrm{AmpBC}$ after release of CPT by treating with $10 \mathrm{mM} \mathrm{GSH}$.
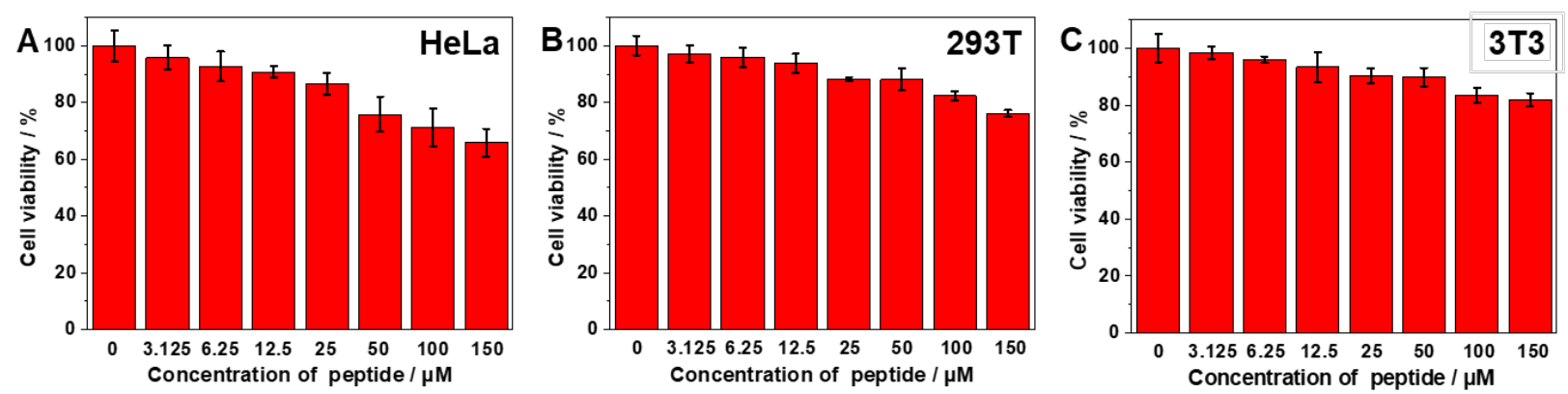

Figure S27. Cell viability of (a) HeLa, (b) 293T, and (c) 3 T3 cells treated with different doses of $\mathrm{Py}^{\mathrm{Me}} \mathrm{Amp}$ after $48 \mathrm{~h}$ incubation. 


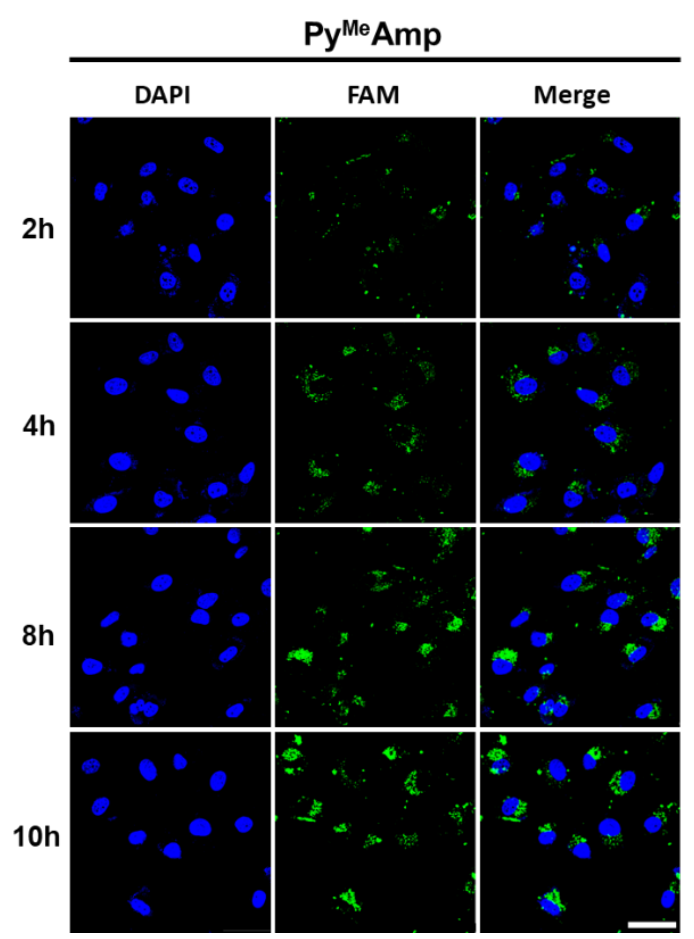

Figure S28. CLSM images of HeLa cells treated with peptide $\mathrm{Py}^{\mathrm{Me}} \mathrm{Amp}$ for 2, 4, 8 or $10 \mathrm{~h}$. Scale bar: $50 \mu \mathrm{m}$.
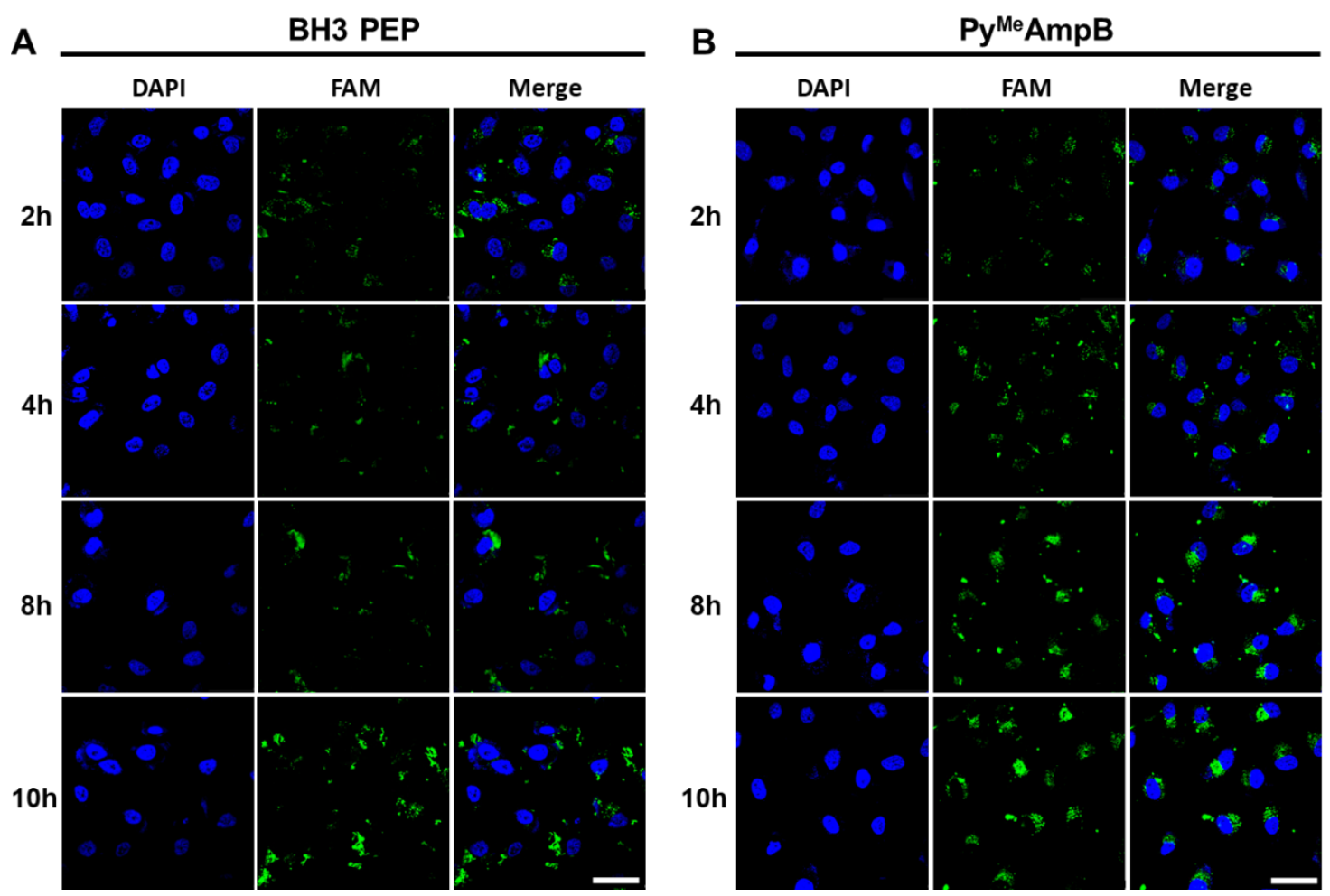

Figure S29. CLSM images of HeLa cells treated with BH3 PEP (A) and $\mathrm{Py}^{\mathrm{Me}} \mathrm{AmpB}$ (B) for 2, 4, 8, and $10 \mathrm{~h}$. Scale bar: $50 \mu \mathrm{m}$. 

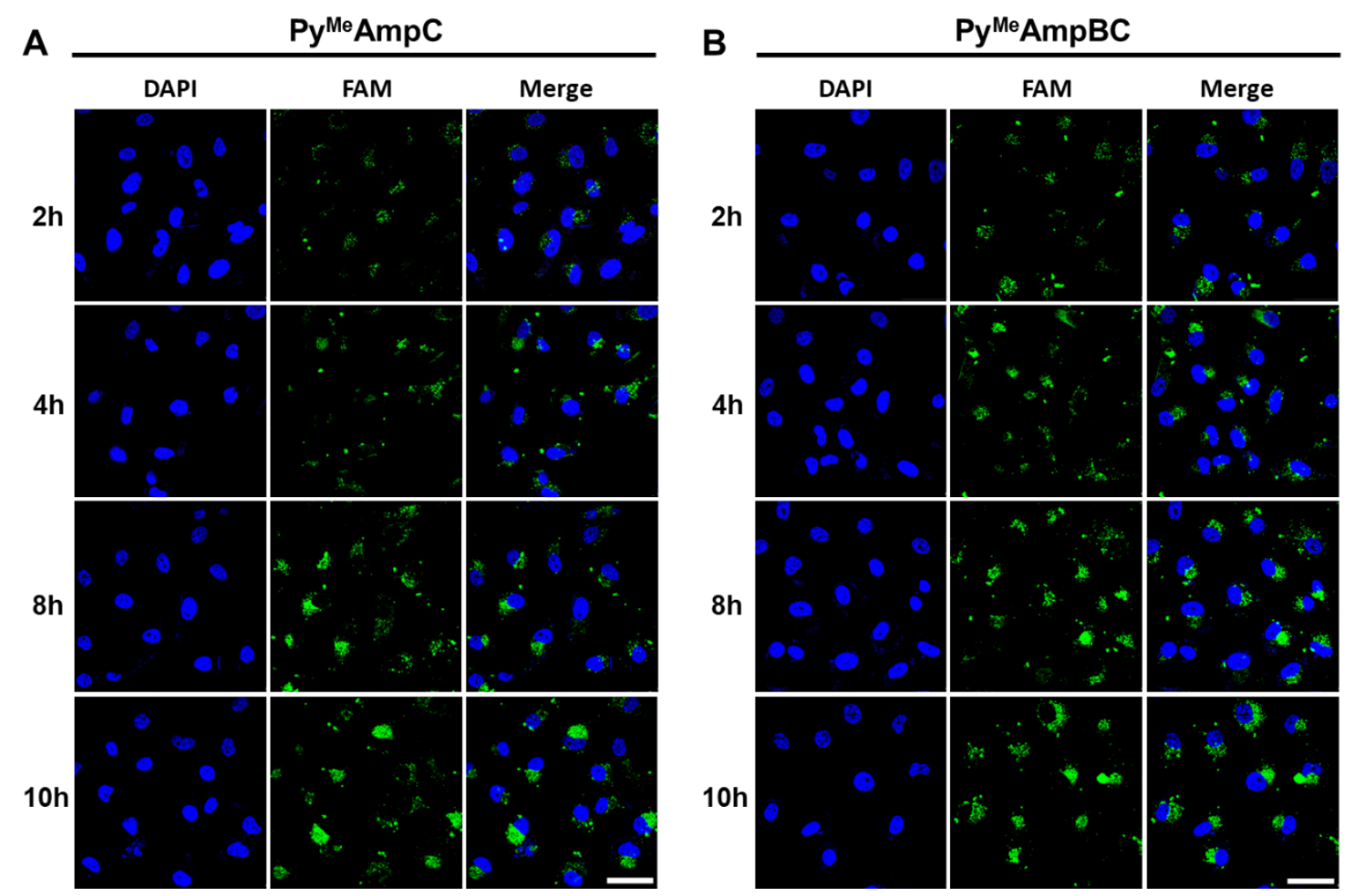

Figure S30. CLSM images of HeLa cells treated with $\mathrm{Py}^{\mathrm{Me}} \mathrm{AmpC}(\mathrm{A})$ and $\mathrm{Py}^{\mathrm{Me}} \mathrm{AmpBC}(\mathrm{B})$ for 2, 4, 8 , and 10 h. Scale bar: $50 \mu \mathrm{m}$.

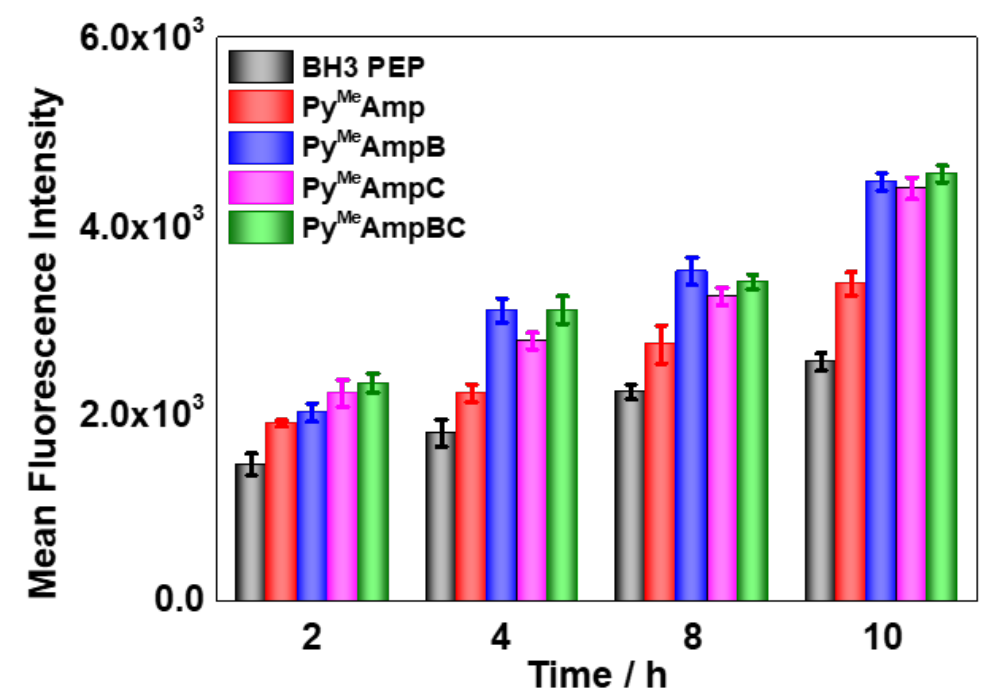

Figure S31. Quantification of the cellular uptaken BH3 PEP, $\mathrm{Py}^{\mathrm{Me}} \mathrm{AmpB}, \mathrm{Py}^{\mathrm{Me}} \mathrm{AmpC}$, and $\mathrm{Py}^{\mathrm{Me}} \mathrm{AmpBC}$ by HeLa cells after incubation for different time points at $\mathrm{pH} 7.4$ measured by CLSM. 


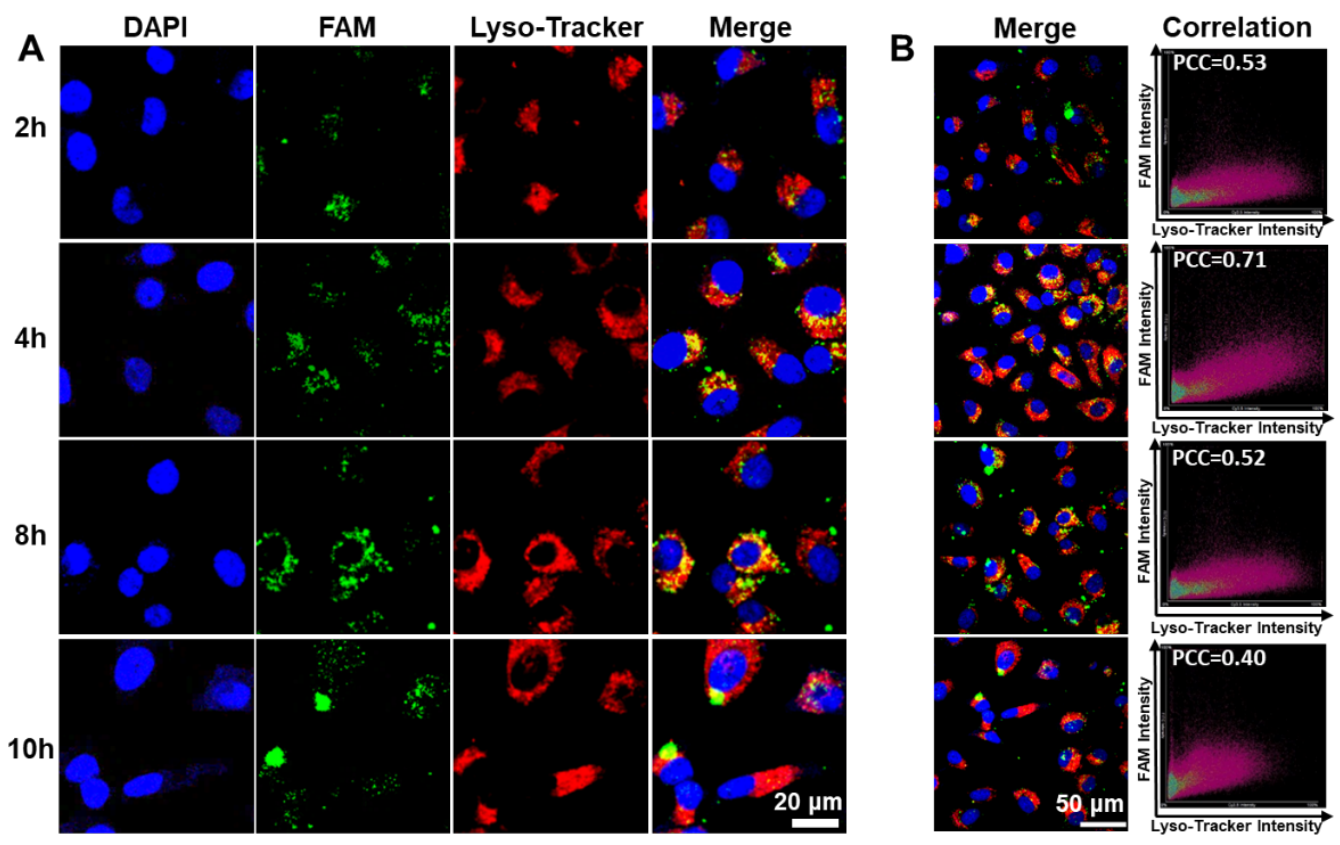

Figure S32. (A) CLSM images and (B) the Pearson's correlation coefficient between Lyso-Tracker and FAM signals of HeLa cells treated with peptide BH3 PEP for 2, 4, 8, and $10 \mathrm{~h}$.

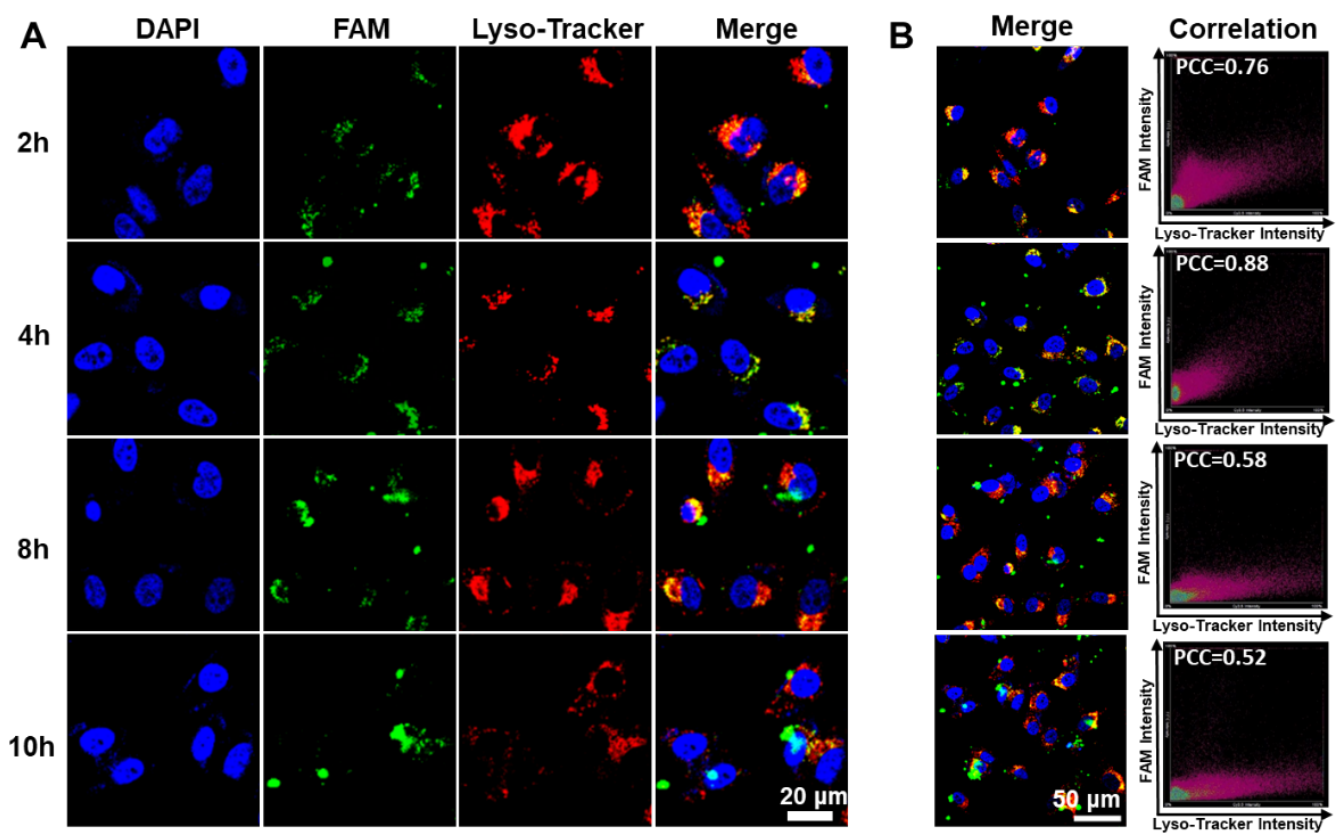

Figure S33. (A) CLSM images and (B) the Pearson's correlation coefficient between Lyso-Tracker and FAM signals of HeLa cells treated with peptide $\mathrm{Py}^{\mathrm{Me}} \mathrm{Amp}$ for 2, 4, 8, and $10 \mathrm{~h}$. 

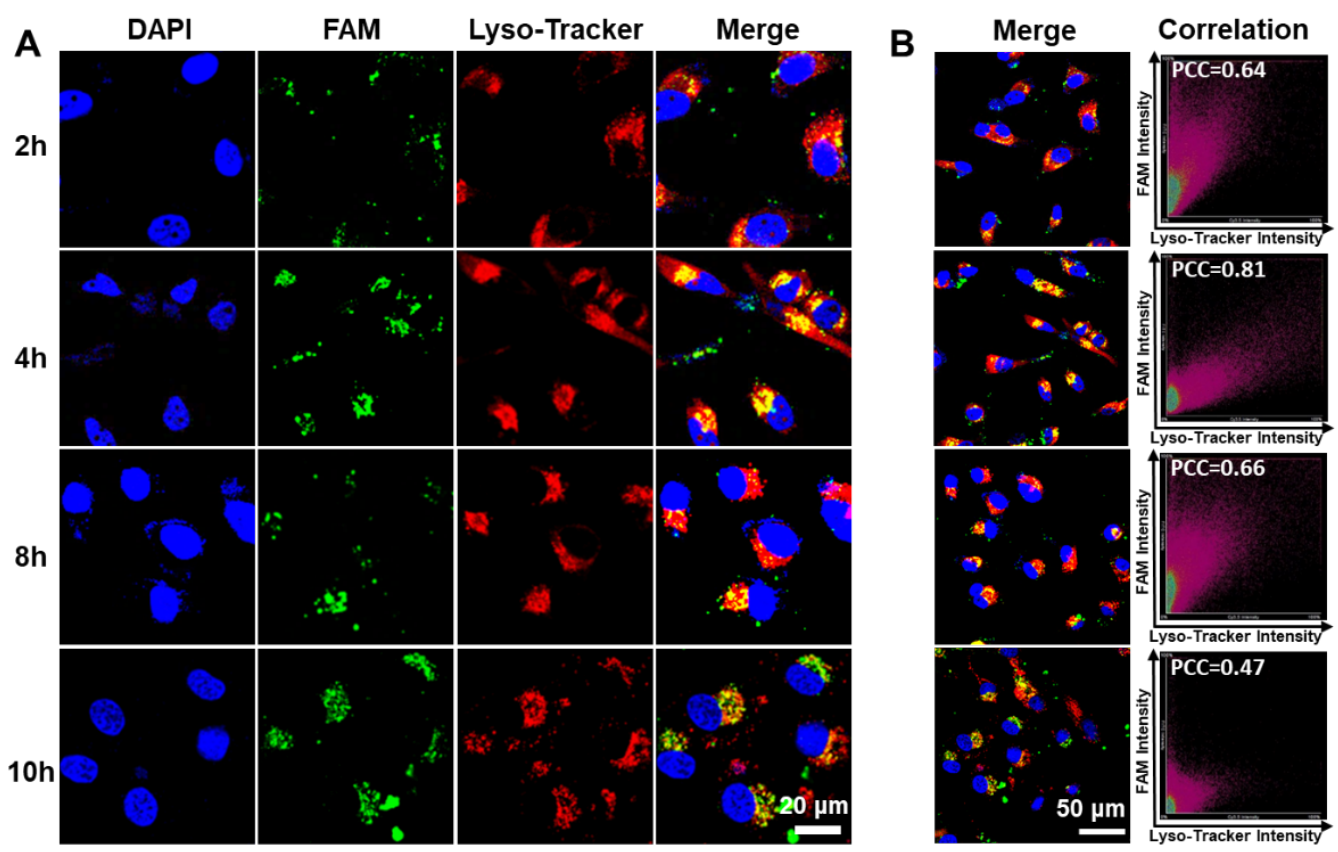

Figure S34. (A) CLSM images and (B) the Pearson's correlation coefficient between Lyso-Tracker Red and FAM signals of HeLa cells treated with $\mathrm{Py}^{\mathrm{Me}} \mathrm{AmpB}$ for 2, 4, 8, and $10 \mathrm{~h}$.
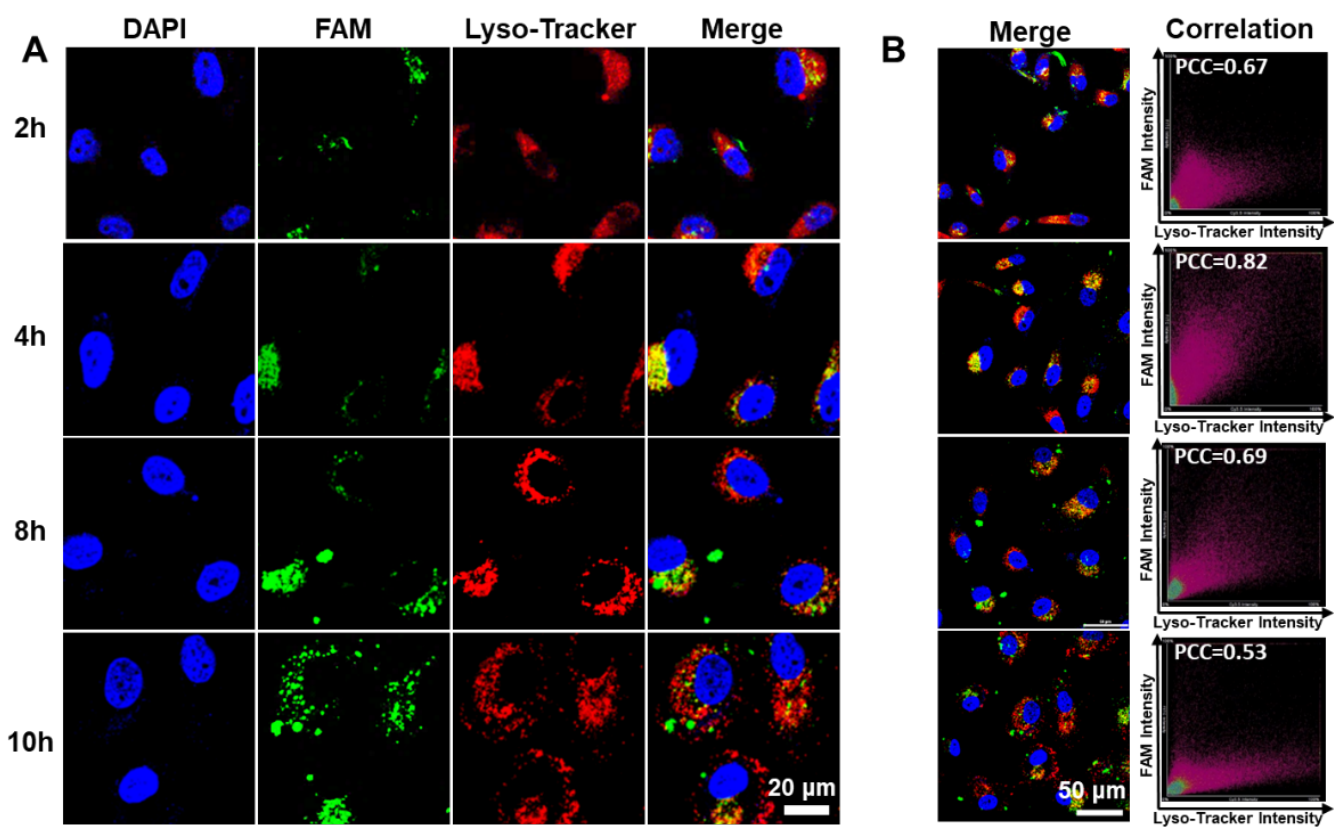

Figure S35. (A) CLSM images and (B) the Pearson's correlation coefficient between Lyso-Tracker Red and FAM signals of HeLa cells treated with $\mathrm{Py}^{\mathrm{Me}} \mathrm{AmpC}$ for 2, 4, 8, and $10 \mathrm{~h}$. 

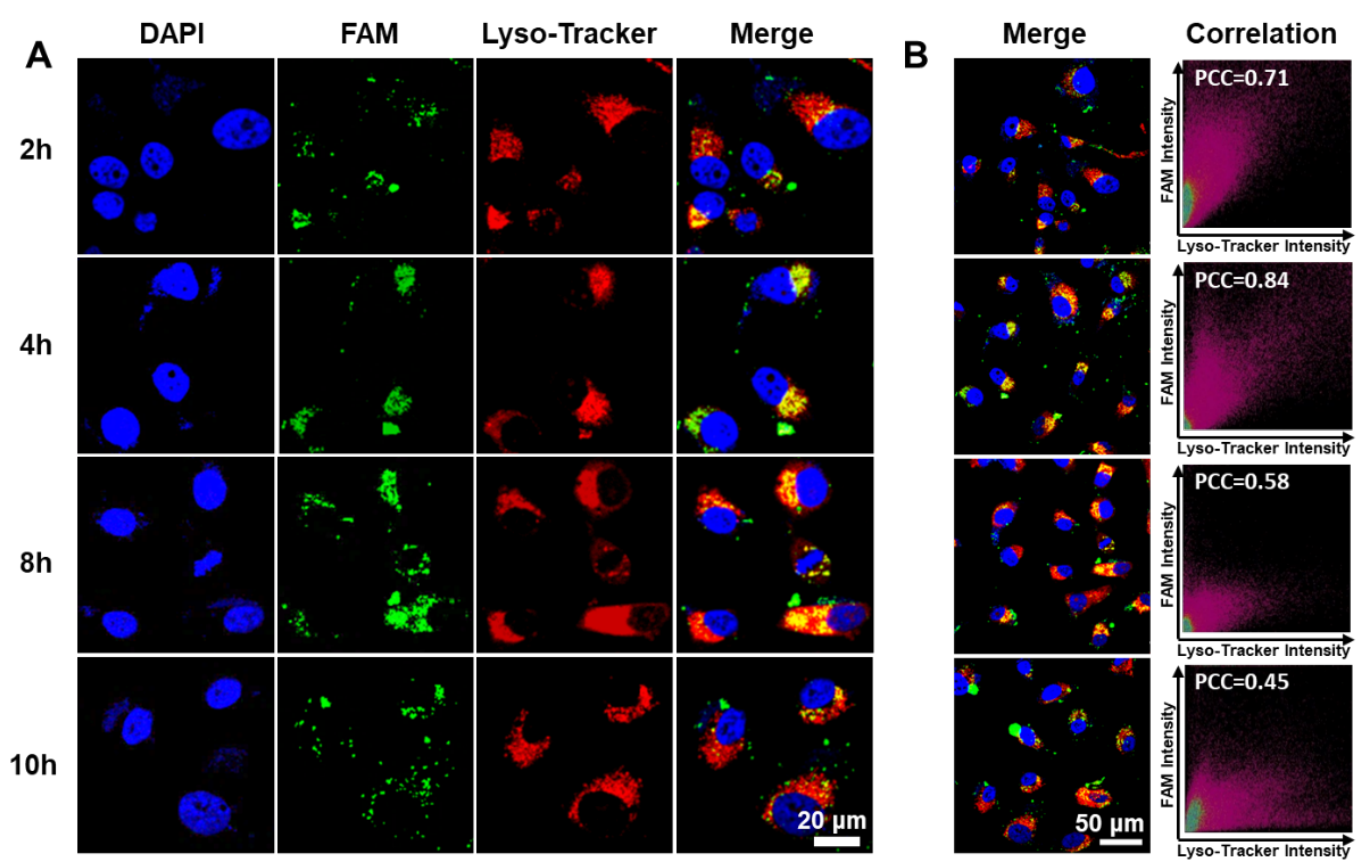

Figure S36. (A) CLSM images and (B) the Pearson's correlation coefficient between Lyso-Tracker Red and FAM signals of HeLa cells treated with $\mathrm{Py}^{\mathrm{Me}} \mathrm{AmpBC}$ for 2, 4, 8, and $10 \mathrm{~h}$.
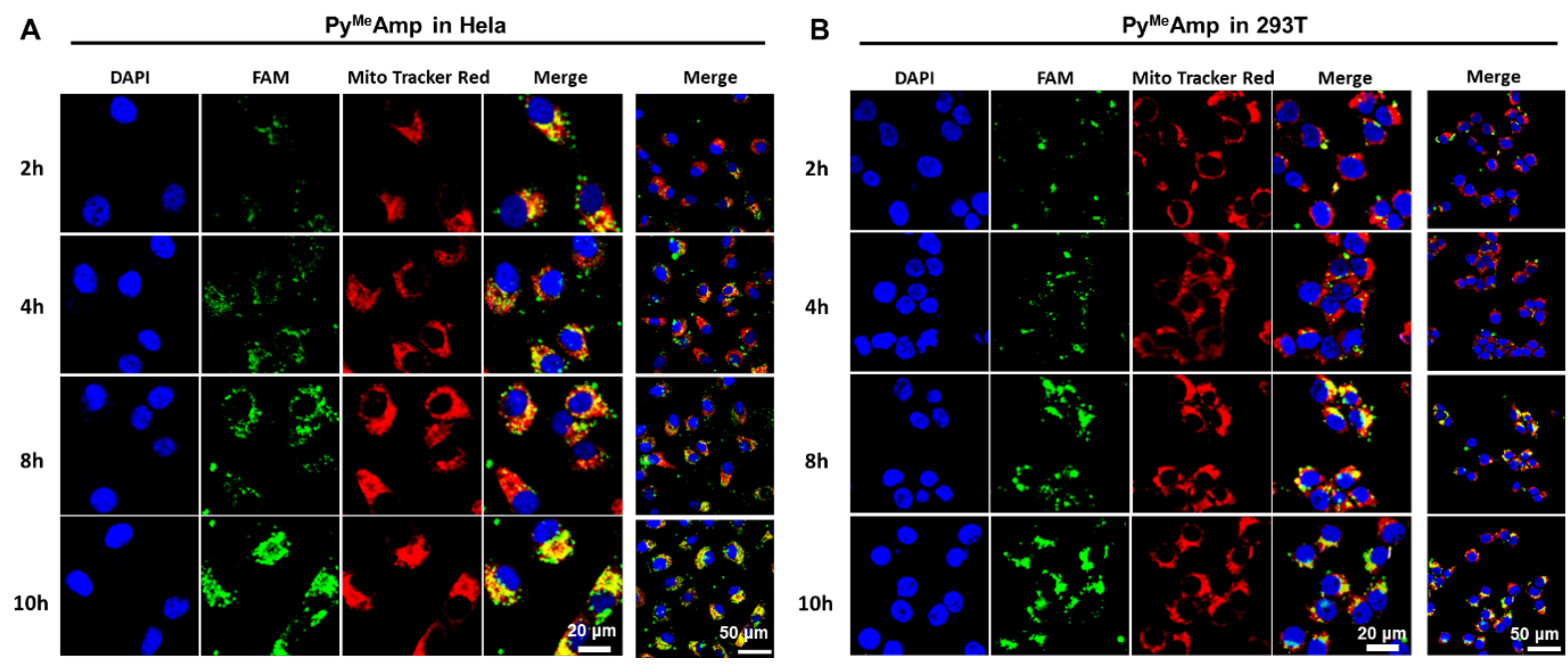

Figure S37. CLSM images between mitochondria and FAM moiety within Hela cells (A) and 293T cells (B) treated with $\mathrm{Py}^{\mathrm{Me}}$ Amp for 2, 4, 8, and $10 \mathrm{~h}$. 

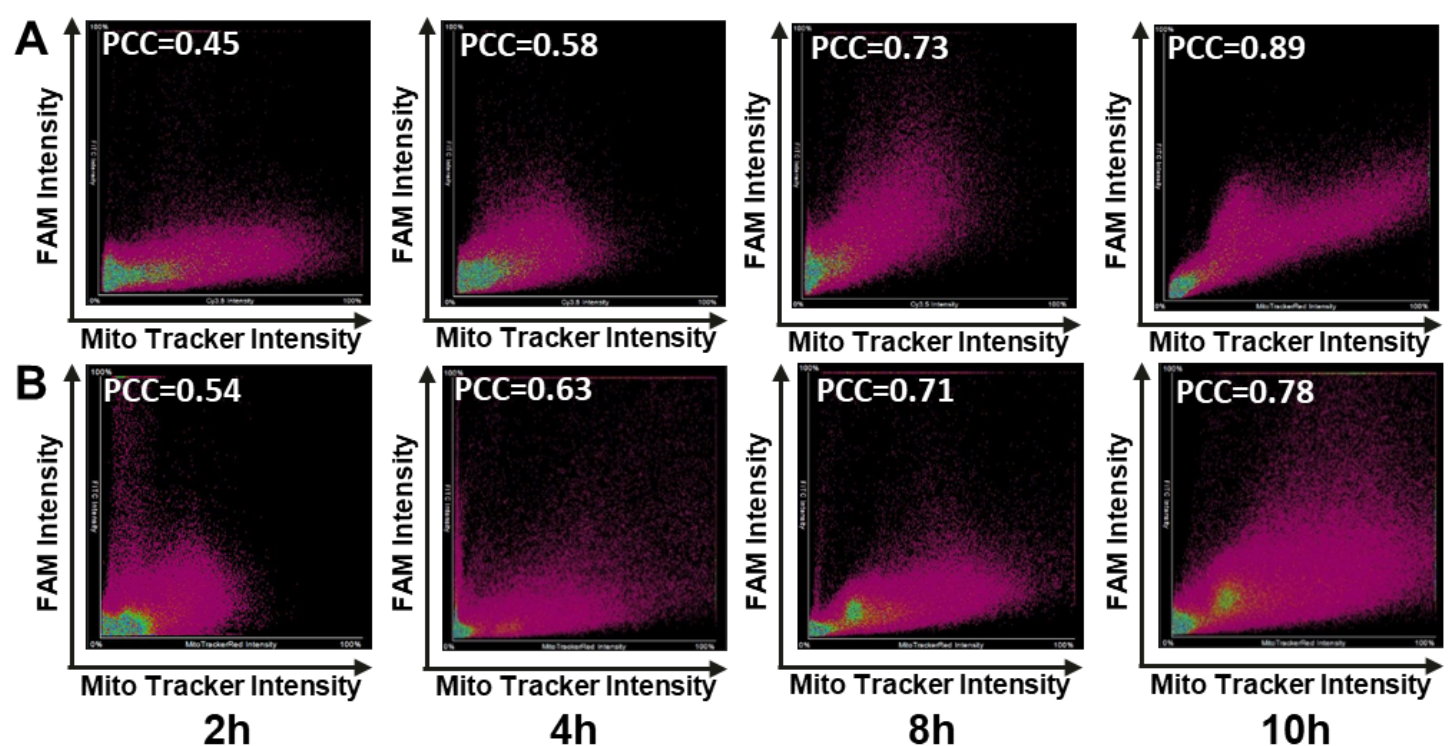

$2 \mathrm{~h}$

$8 \mathrm{~h}$

10h

Figure S38. The Pearson's correlation coefficient between Mito-Tracker and FAM signals within HeLa cells (A) and $293 \mathrm{~T}$ cells (B) treated with $\mathrm{Py}^{\mathrm{Me}} \mathrm{Amp}$ at different incubation time points (2, 4, 8 and $10 \mathrm{~h}$ ).
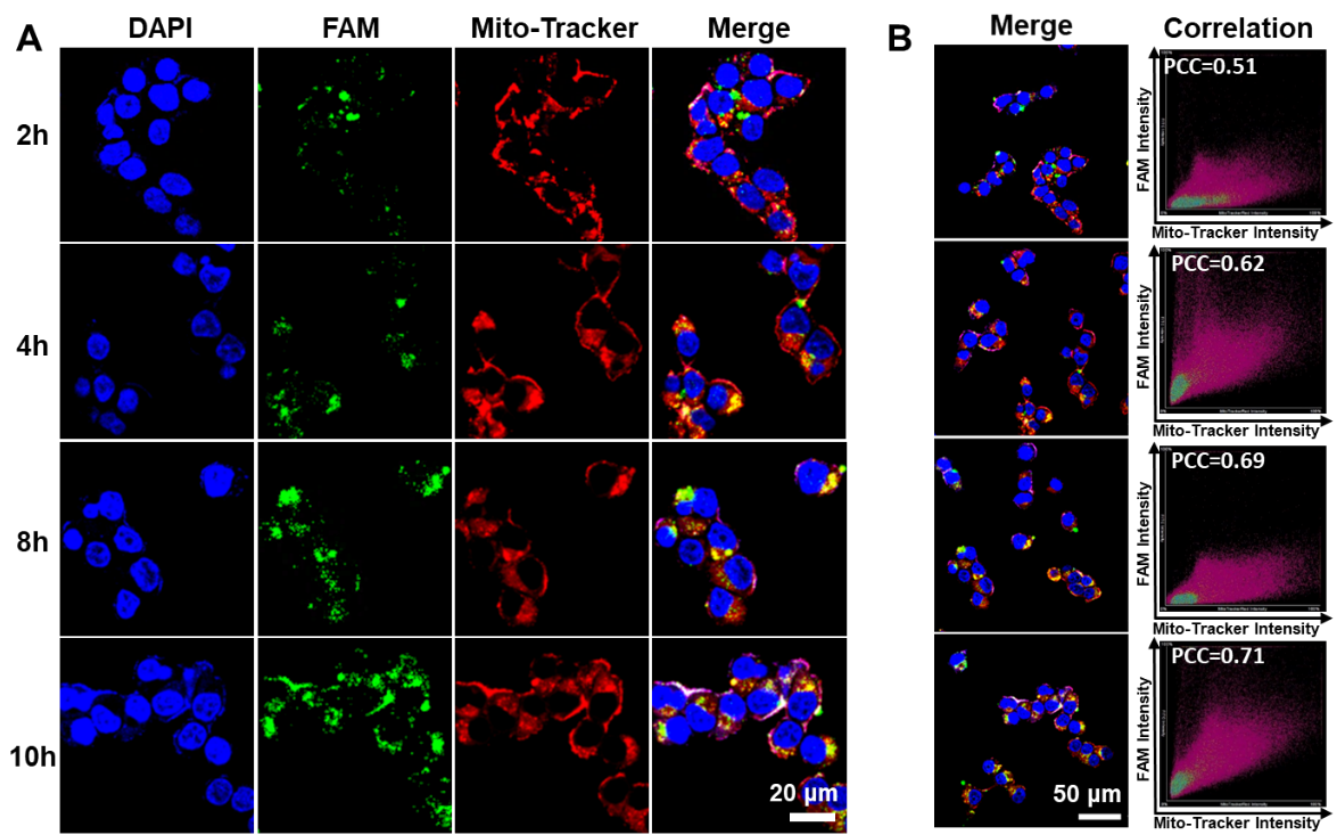

Figure S39. (A) CLSM images and (B) the Pearson's correlation coefficient between Mito-Tracker and FAM signals of $293 \mathrm{~T}$ cells treated with $\mathrm{Py}^{\mathrm{Me}} \mathrm{AmpBC}$ for 2, 4, 8, and $10 \mathrm{~h}$. 


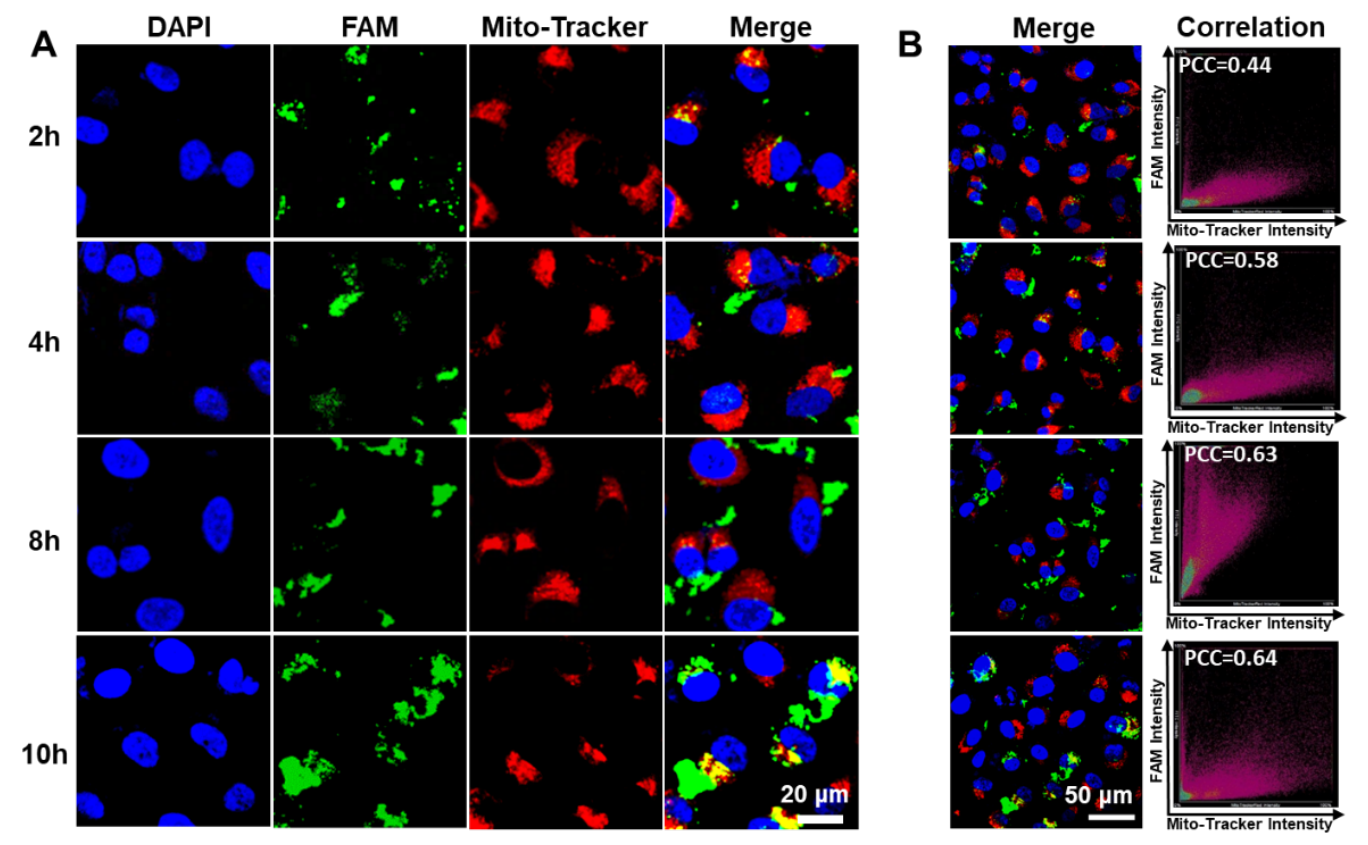

Figure S40. (A) CLSM images and (B) the Pearson's correlation coefficient between Mito-Tracker and FAM signals of HeLa cells treated with BH3 PEP for 2, 4, 8, and $10 \mathrm{~h}$.
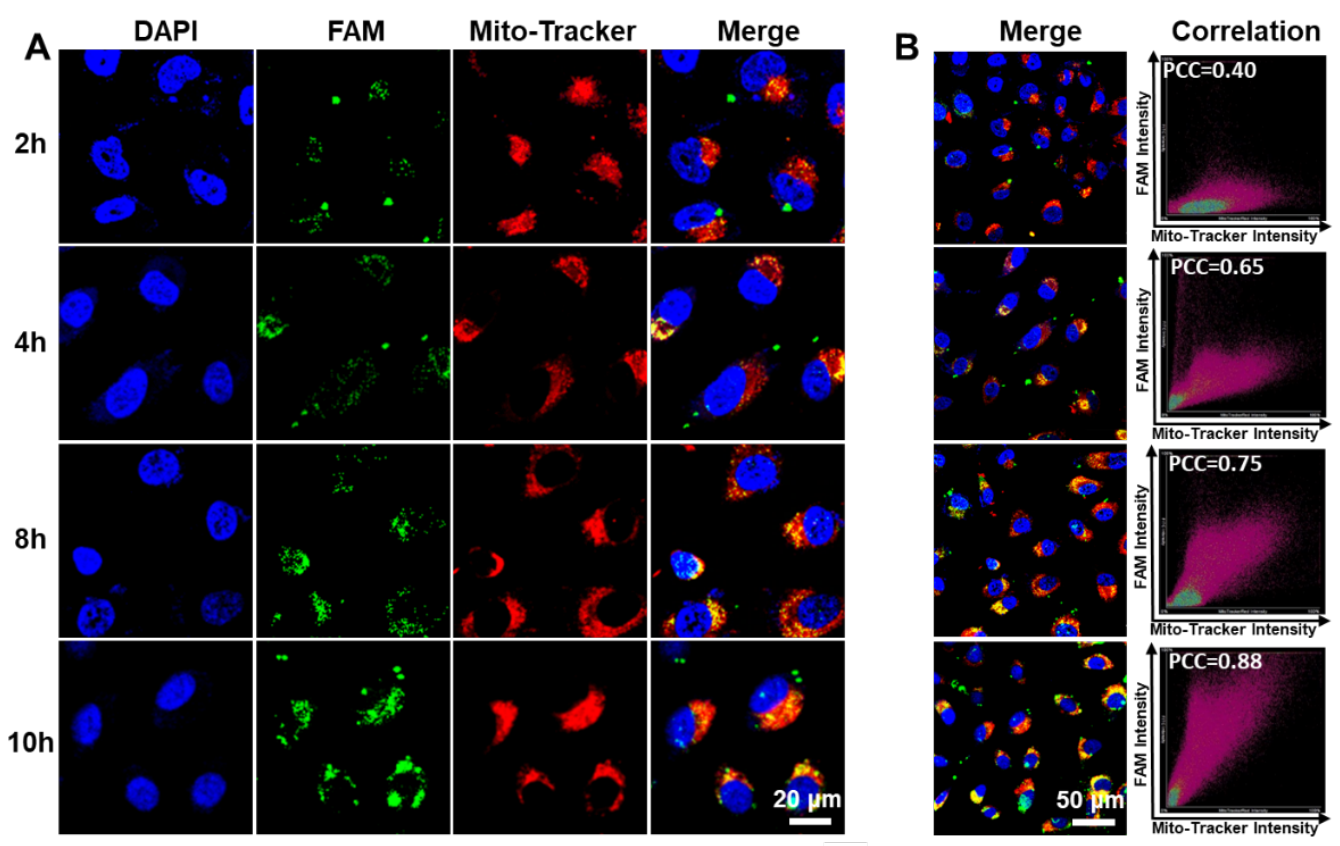

Figure S41. (A) CLSM images and (B) the Pearson's correlation coefficient between Mito-Tracker and FAM signals of HeLa cells treated with $\mathrm{Py}^{\mathrm{Me}} \mathrm{AmpB}$ for 2, 4, 8, and $10 \mathrm{~h}$. 

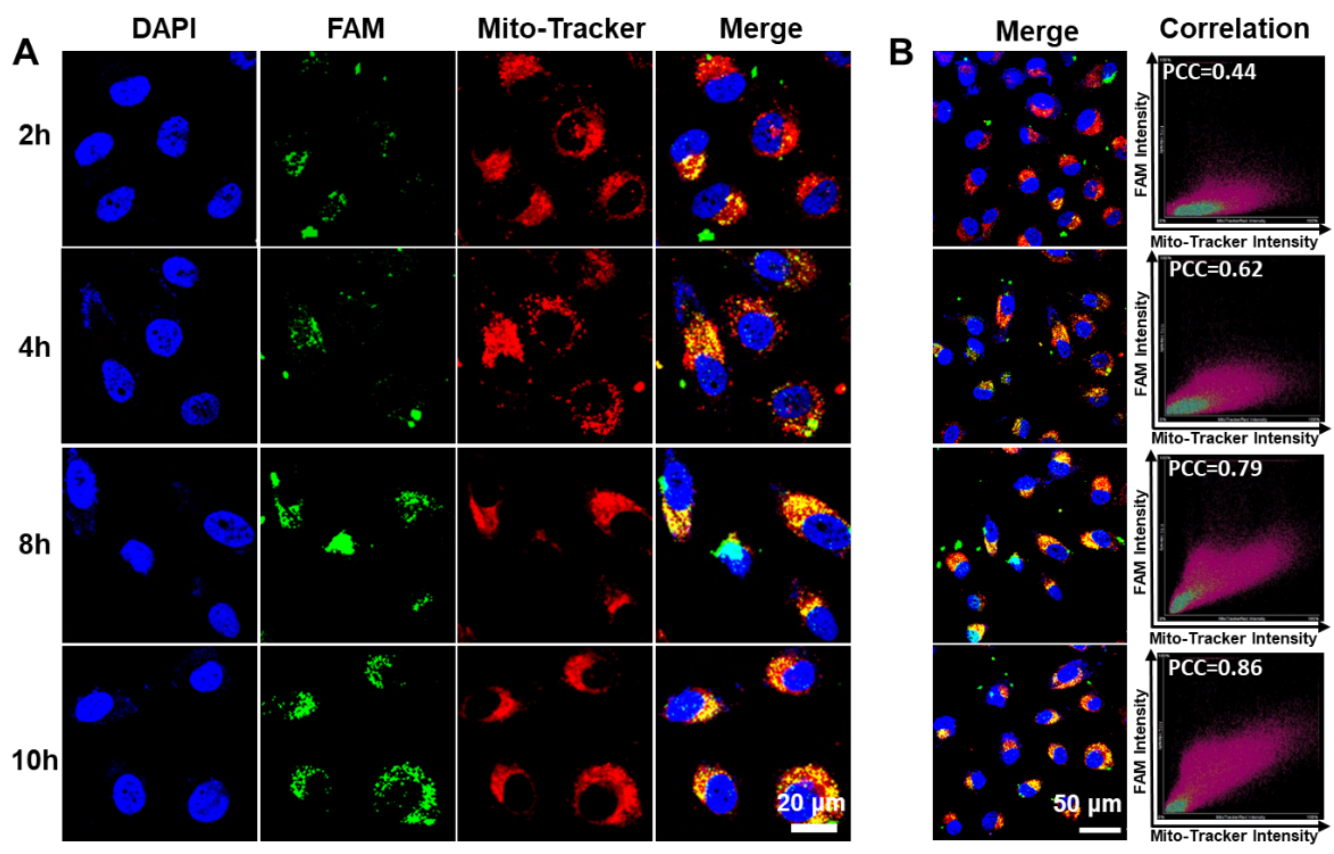

Figure S42. (A) CLSM images and (B) the Pearson's correlation coefficient between Mito-Tracker and FAM signals of HeLa cells treated with $\mathrm{Py}^{\mathrm{Me}} \mathrm{AmpC}$ for 2, 4, 8, and $10 \mathrm{~h}$.
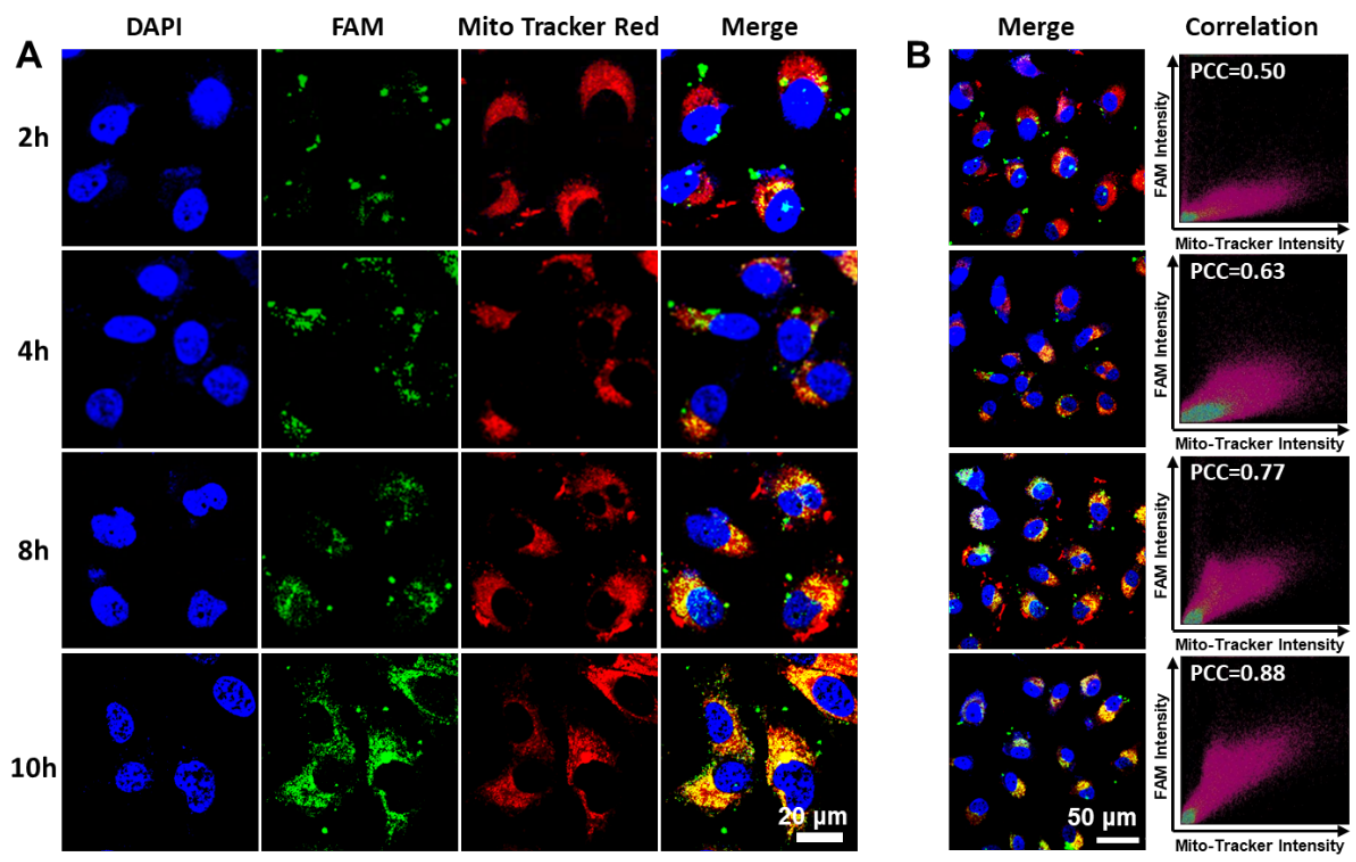

Figure S43. (A) CLSM images and (B) the Pearson's correlation coefficient between Mito-Tracker and FAM signals of HeLa cells treated with $\mathrm{Py}^{\mathrm{Me}} \mathrm{AmpBC}$ for 2, 4, 8, and $10 \mathrm{~h}$. 


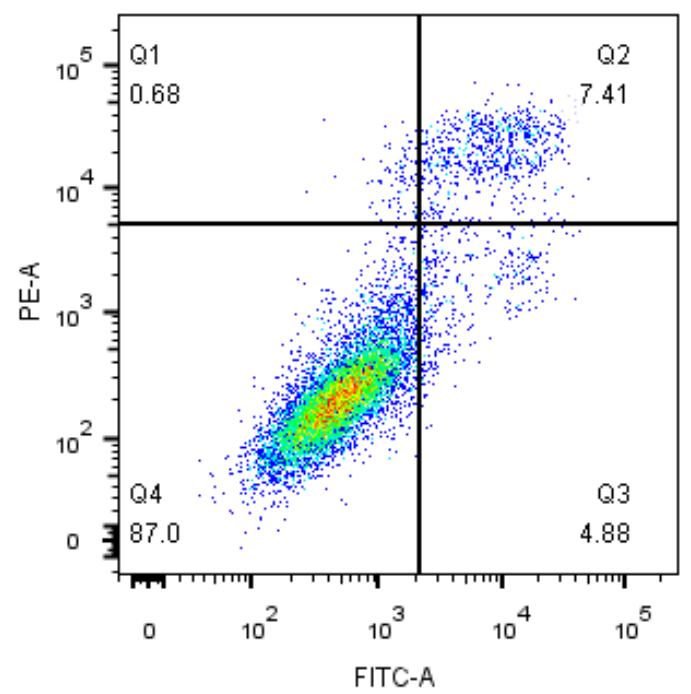

Figure S44. Flow cytometric analysis the cellular apoptosis of HeLa cells with PBS at 48 h by staining with annexin V-FITC and PI.

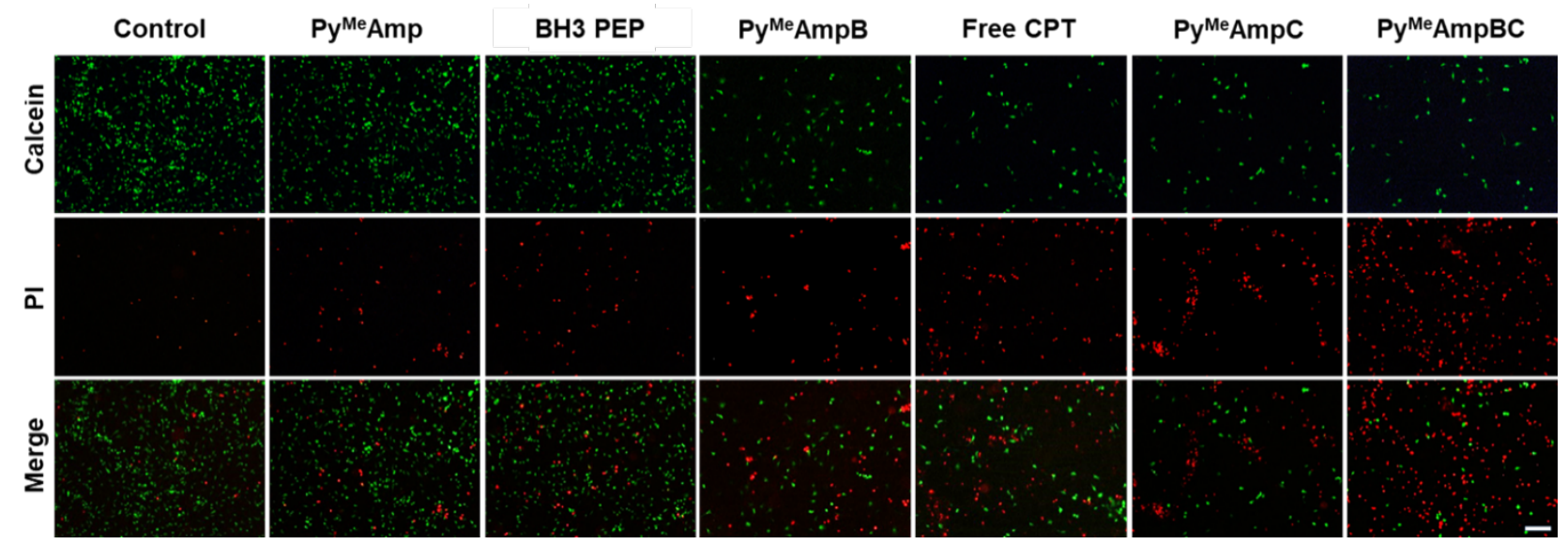

Figure S45. Fluorescence images of Calcein/PI stained HeLa cells after treatment with PBS, and $\mathrm{Py}^{\mathrm{Me}}$ Amp, BH3 PEP, Py ${ }^{\mathrm{Me}} \mathrm{AmpB}$, free CPT, $\mathrm{Py}^{\mathrm{Me}} \mathrm{AmpC}$, and $\mathrm{Py}^{\mathrm{Me}} \mathrm{AmpBC}$. Scale bar: $100 \mu \mathrm{m}$. 


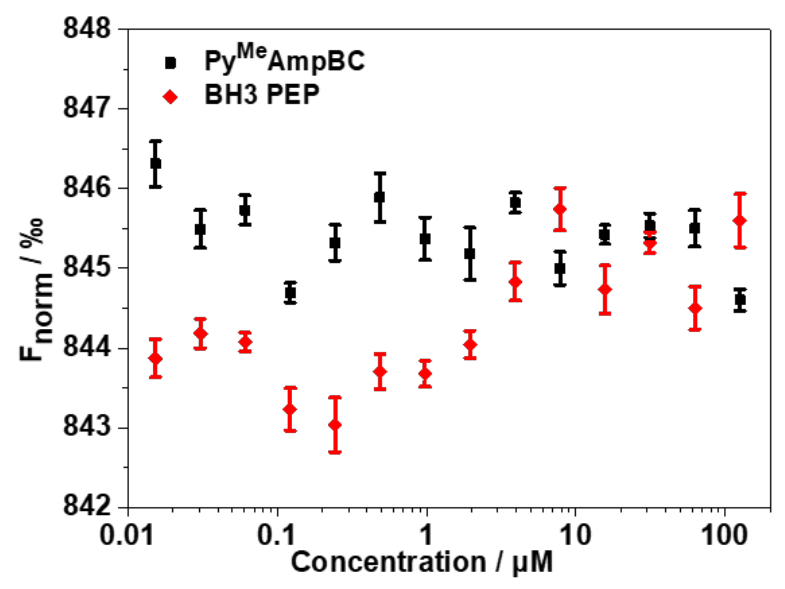

Figure S46. Microsccale thermophoresis analysis of the binding constant between BH3 PEP or $\mathrm{Py}^{\mathrm{Me}} \mathrm{AmpBC}$ and Bax protein as a function of the substrate concentration.
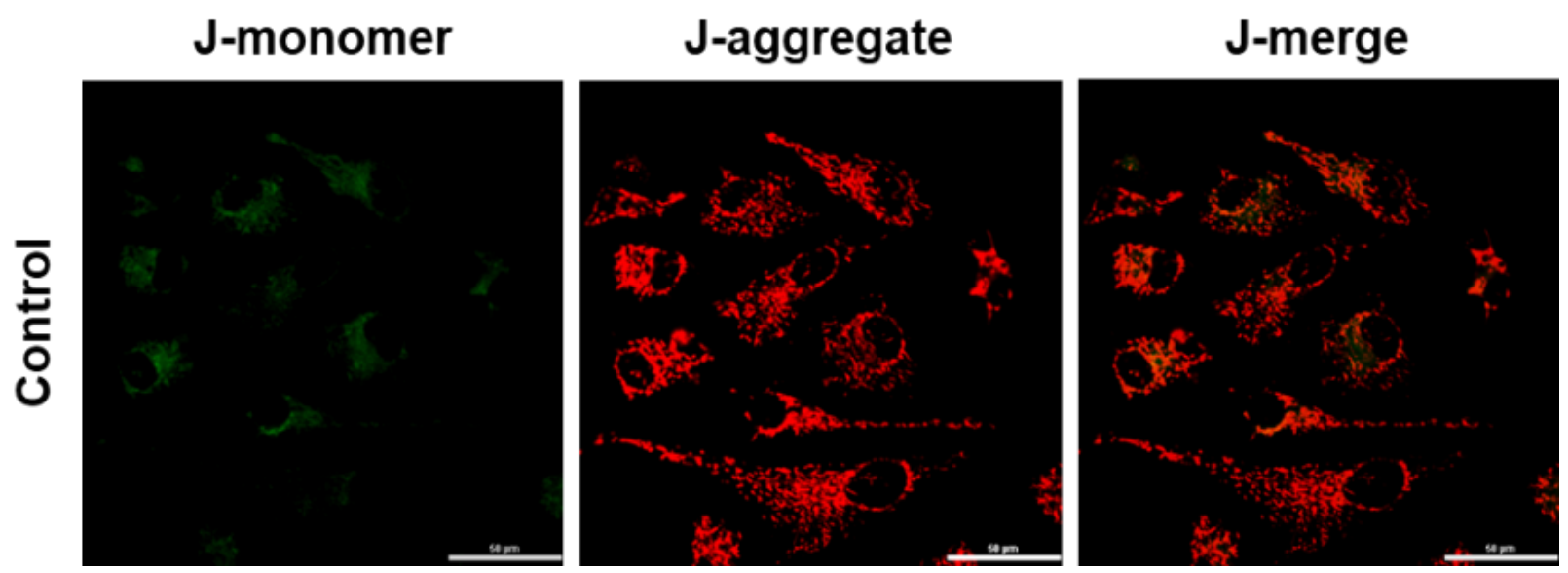

Figure S47. Fluorescence images of JC-1-labeled mitochondrial membrane of HeLa cells with PBS. Scale bar: $50 \mu \mathrm{m}$. 

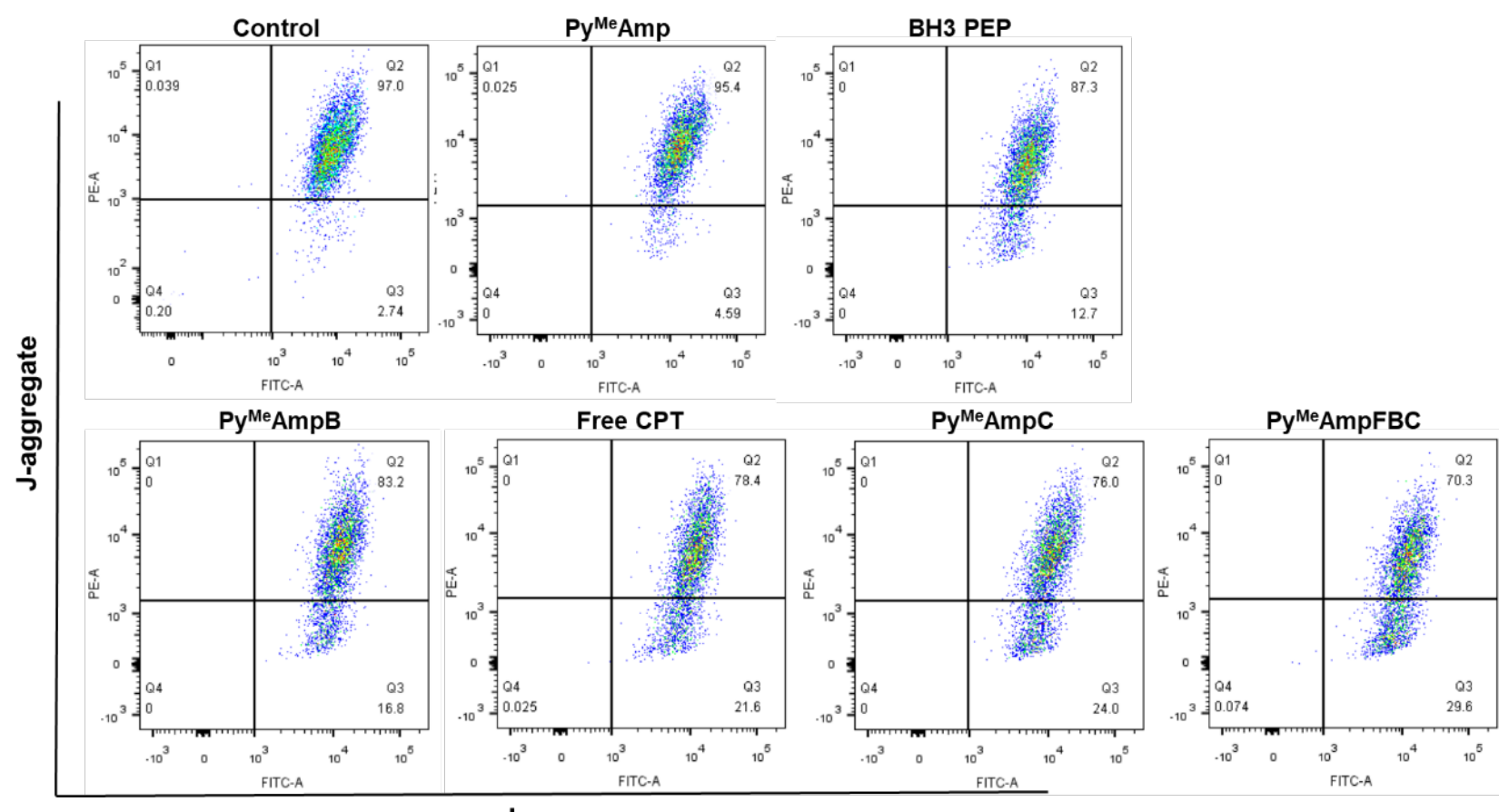

J-monomer

Figure S48. Flow cytometric analysis of HeLa cells treated with PBS, $\mathrm{Py}^{\mathrm{Me}} \mathrm{Amp}, \mathrm{BH} 3 \mathrm{PEP}$, $\mathrm{Py}^{\mathrm{Me}} \mathrm{AmpB}$, free CPT, $\mathrm{Py}^{\mathrm{Me}} \mathrm{AmpC}$, and $\mathrm{Py}^{\mathrm{Me}} \mathrm{AmpBC}$ for estimating the mitochondrial membrane potential.
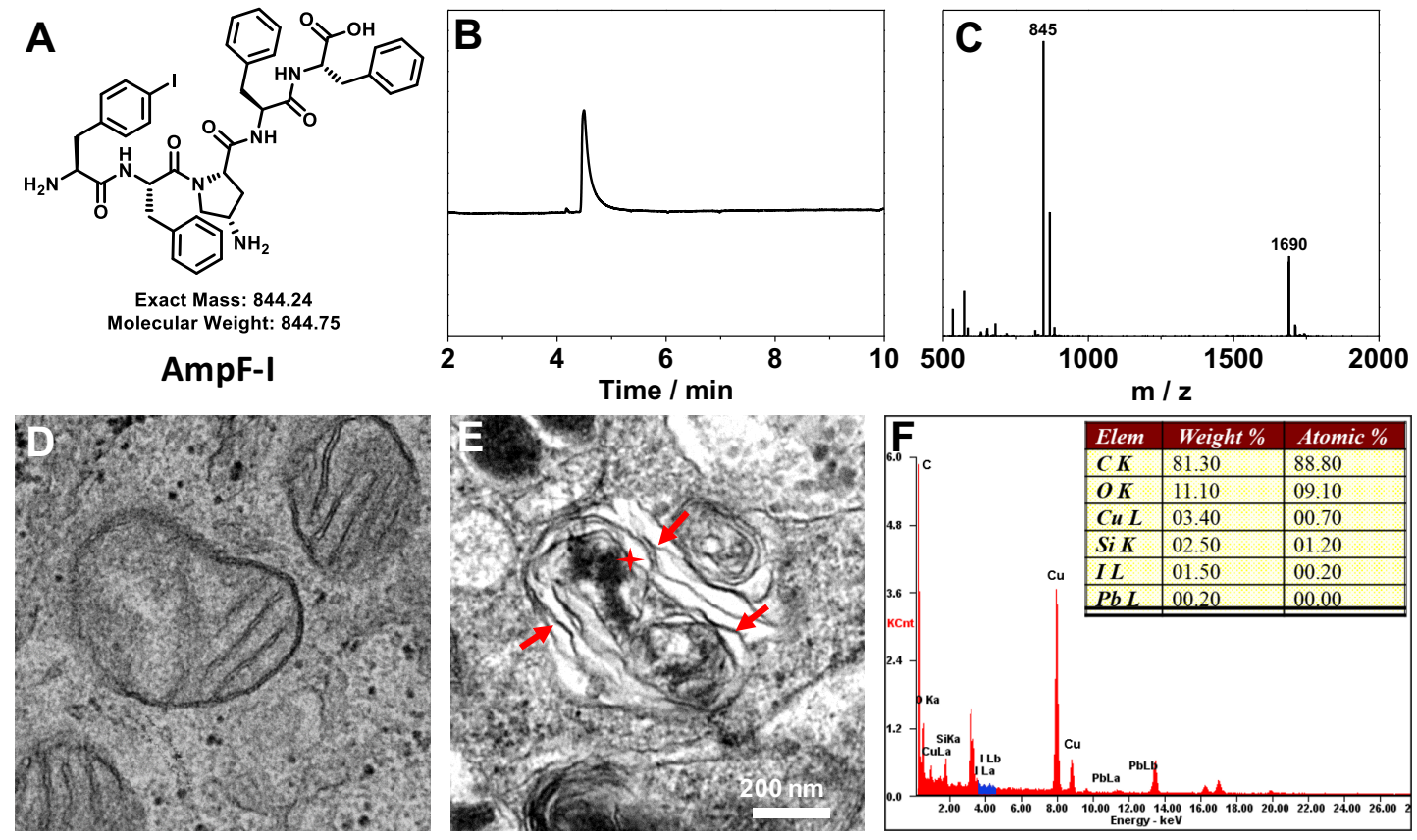

Figure S49. Chemical structure (A), UPLC trace (B), and mass spectrum (C) of peptide AmpF-I. BioTEM images of Hela cells incubated in the presence of PBS (D) or Py ${ }^{\mathrm{Me}} \mathrm{AmpBC}-\mathrm{I}$ (E) for $10 \mathrm{~h}$. (F) The corresponding energy-dispersive X-ray spectrum (EDS) of the nanofibers indicated by red arrows. 
Bio-TEM image of HeLa cells treated by $\mathrm{Py}^{\mathrm{Me}} \mathrm{AmpBC}-\mathrm{I}$ showed obvious nanofibrils surrounding mitochondria and damaged mitochondria within cytoplasm, whereas the cells treated with PBS exhibited intact mitochondria and the absence of one-dimensional nanostructures. EDS analysis of the elements along the nanofibers detect iodine. Therefore, the bio-TEM studies directly confirm the accumulation of the supramolecular antagonist $\mathrm{Py}^{\mathrm{Me}} \mathrm{AmpBC}$ at mitochondria and thereby causing their dysfunction.

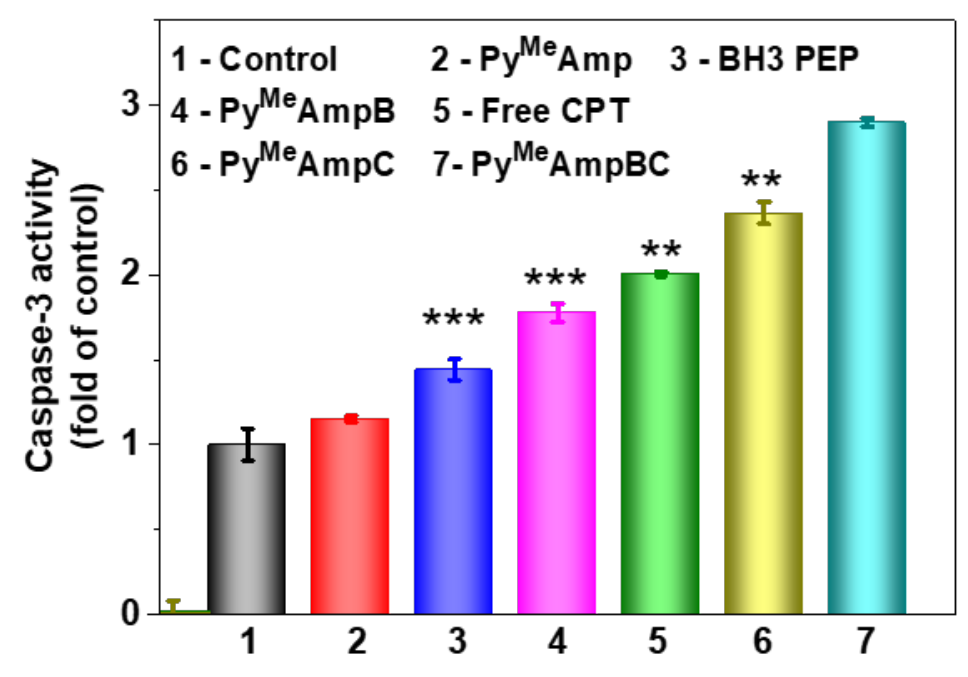

Figure S50. Activities of caspase 3 within HeLa cells treated with PBS, $\mathrm{Py}^{\mathrm{Me}} \mathrm{Amp}, \mathrm{BH} 3$ PEP, $\mathrm{Py}^{\mathrm{Me}} \mathrm{AmpB}$, free CPT, Py ${ }^{\mathrm{Me}} \mathrm{AmpC}$, and $\mathrm{Py}^{\mathrm{Me}} \mathrm{AmpBC}$ for $12 \mathrm{~h}$. 


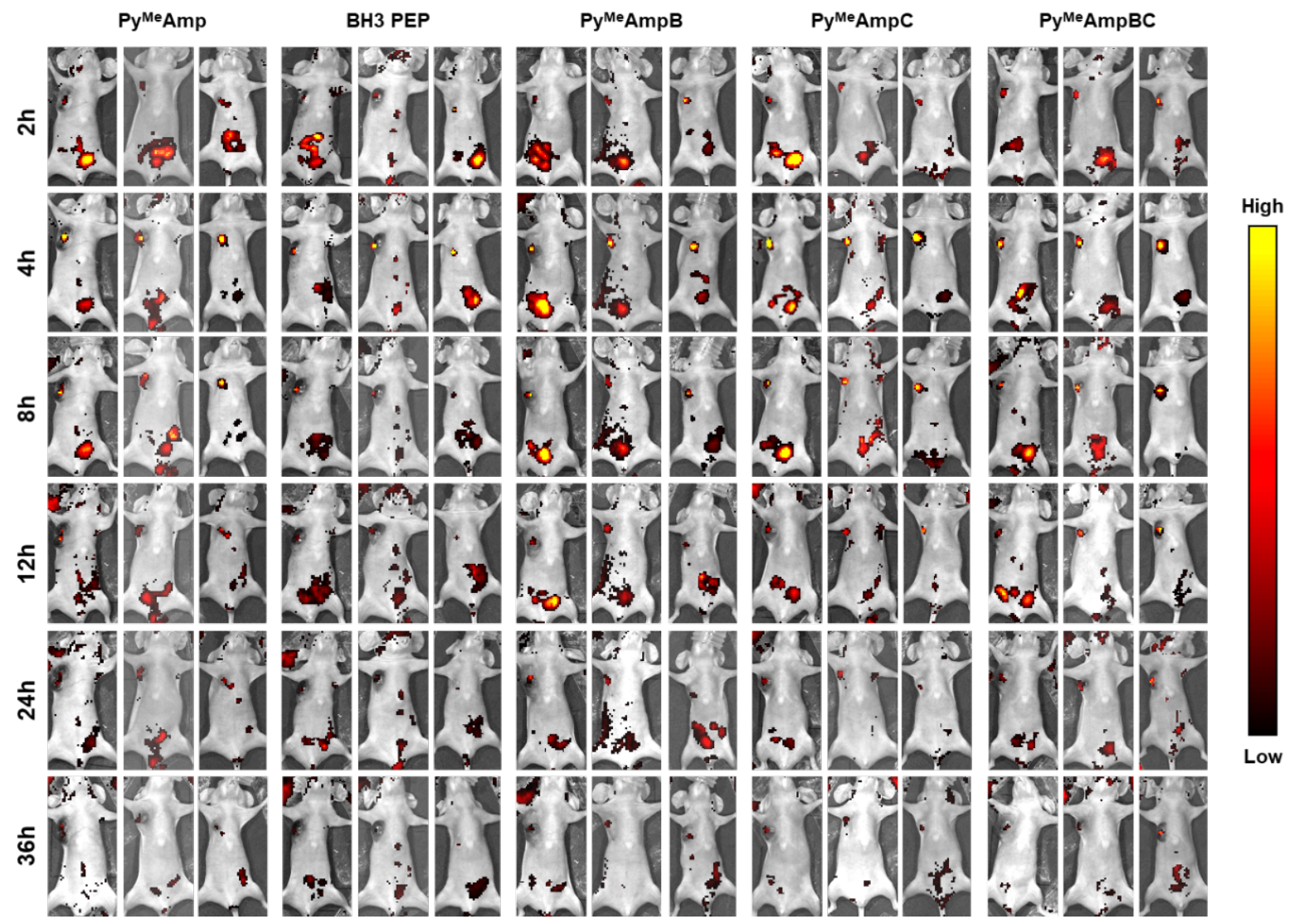

Figure S51. In vivo fluorescence imaging of tumor-bearing mice after administration of $\mathrm{Py}^{\mathrm{Me}} \mathrm{Amp}$, BH3 PEP, $\mathrm{Py}^{\mathrm{Me}} \mathrm{AmpB}, \mathrm{Py}^{\mathrm{Me}} \mathrm{AmpC}$, or $\mathrm{Py}^{\mathrm{Me}} \mathrm{AmpBC}$ for 2, 4, 8, 12, 24, and $36 \mathrm{~h}$.

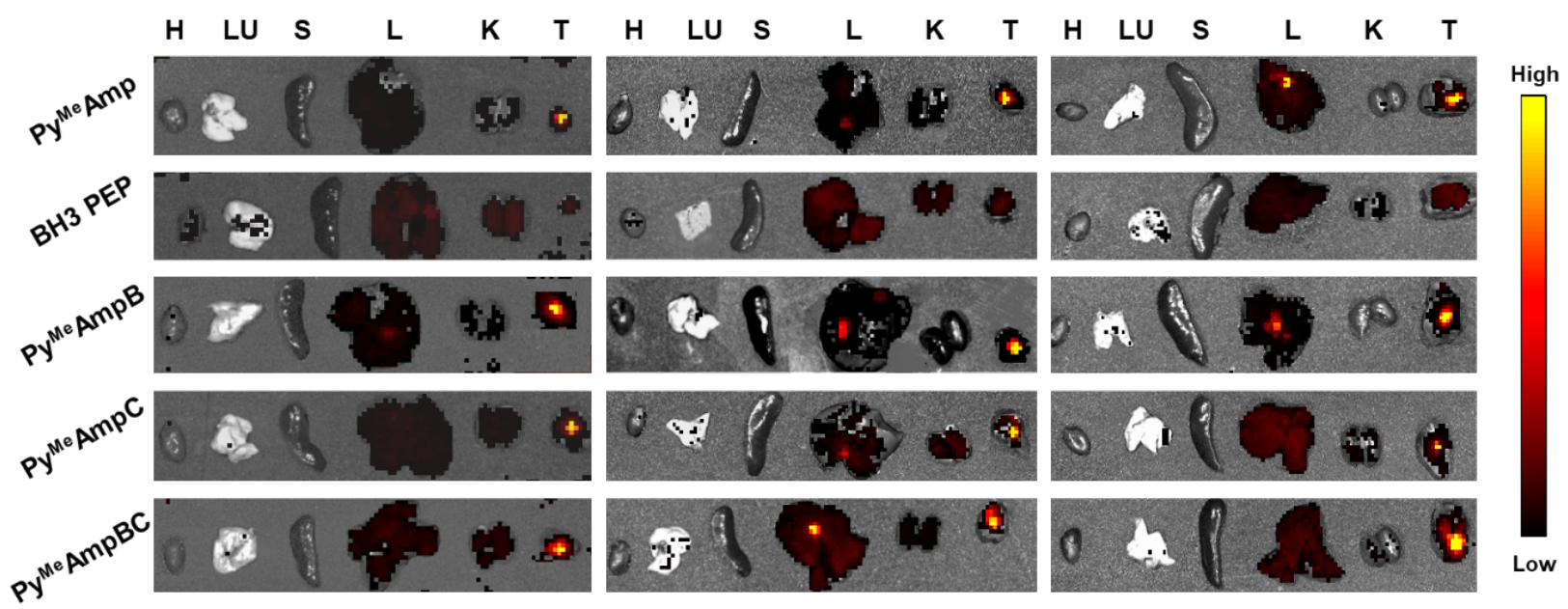

Figure S52. Ex vivo fluorescence imaging of tumors (T) and major tissues (H: heart; LU: lung; S: spleen; L: liver; K: kidney) dissected from mice at $36 \mathrm{~h}$ post-administration of different treatments. 


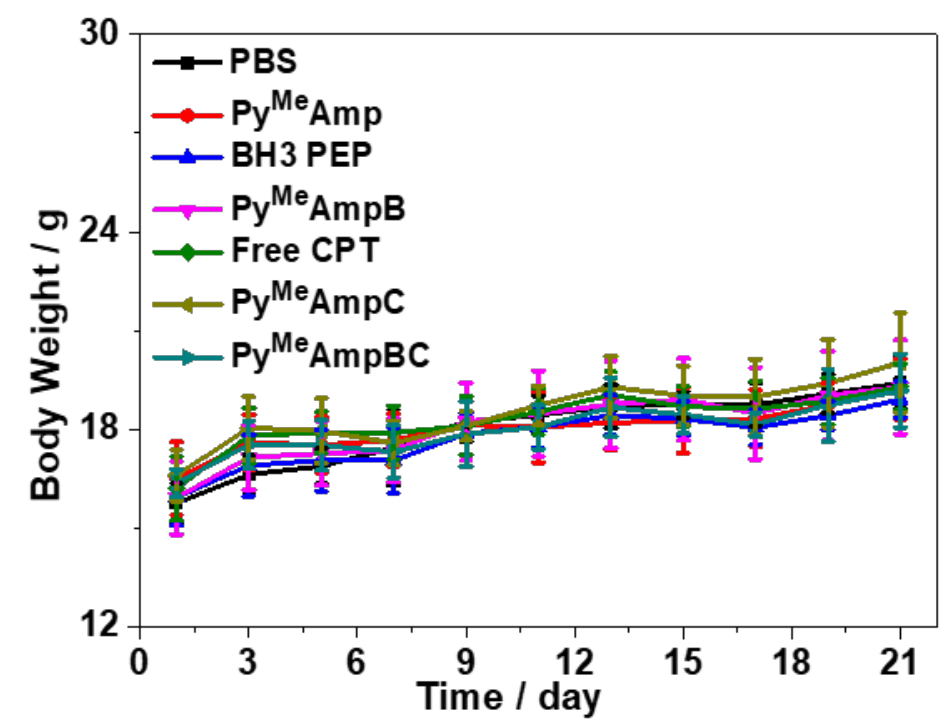

Figure S53. Body weight changes of the mice administrated with different treatments.

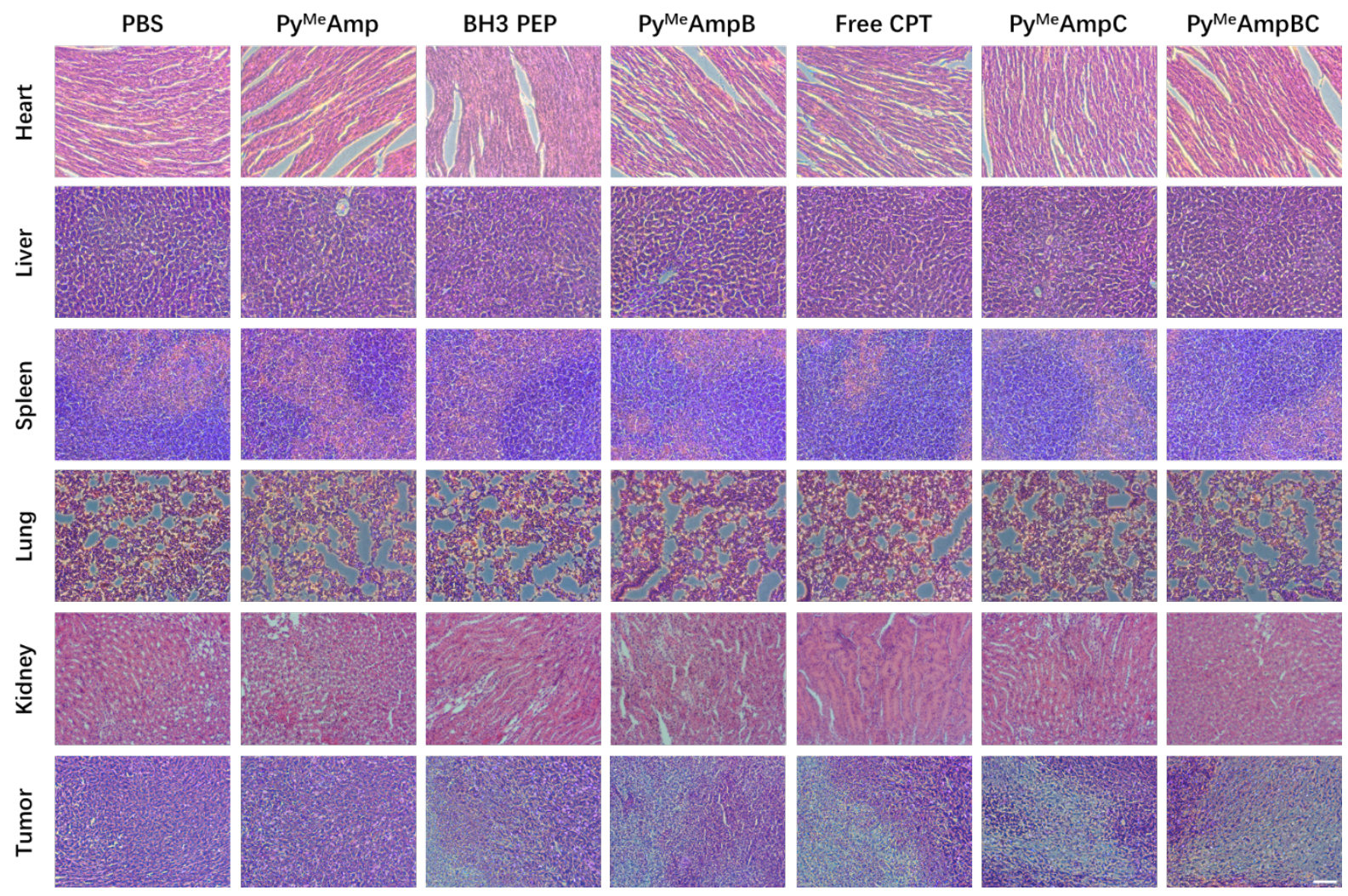

Figure S54. H\&E staining images of normal tissues (heart, liver, spleen, lung, and kidney) and tumors collected at day 21 post-administration from the mice with different treatments. Scale bar: $200 \mu \mathrm{m}$.

\section{References}

[1] Jones, L.R.; Goun, E.A.; Shinde, R.; Rothbard, J.B.; Contag, C.H.; Wender, P. A. J. Am. Chem. 
Soc, 2006, 128, 6526-6527.

[2] Muniesa, C.; Vicente, V.; Quesada, M.; Sáez-Atiénzar, S.; Blesa, J. R.; Abasolo, I.; Fernández, Y.; Botella, P. RSC Adv, 2013, 3, 15121-15131.

[3] Salgado, J.; García- Sáez, A. J.; Malet, G.; Mingarro, I.; Pérez- Payá, E. J. Peptide Sci, 2002, 8, 543-560.

[4] Cheng, D.; Wang, D.; Gao,Y.; Wang, L.; Qiao, Z.; Wang, H. J. Am. Chem. Soc, 2019, 141, 44064411. 